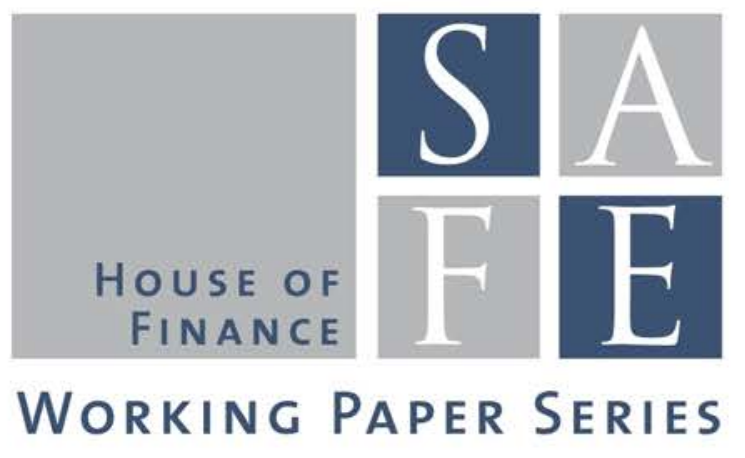

Michael J. Brennan - Holger Kraft

\title{
Leaning against the Wind: Debt Financing in the Face of Adversity
}

SAFE Working Paper No. 119

SAFE I Sustainable Architecture for Finance in Europe A cooperation of the Center for Financial Studies and Goethe University Frankfurt 


\section{Non-Technical Summary}

We provide empirical evidence that financing decisions do depend on expectations about future profitability. We find that, after allowing for asset growth and mean reversion in profitability, debt financing has strong predictive power for future changes in profitability as measured by the Return on Assets. While asset growth and the total amount of external financing tend to be associated with higher future profitability, increased reliance on debt financing is associated with a lower future return on assets. Since the amount of debt financing is a managerial choice variable, this implies that managers have information about the change in future profitability at the time of the financing and choose to issue more debt when future earnings prospects are relatively poor. This behavior which we term 'leaning against the wind', appears to be inconsistent with the traditional static tax and bankruptcy model which would predict a decline in debt capacity and a corresponding decline in debt financing in these circumstances. The relation between debt financing and future changes in the Return on Equity is much weaker but in the same direction.

We consider three possible explanations for leaning against the wind: market timing, precautionary financing combined with pecking order financing, and 'making the numbers'.

The market timing (MT) hypothesis is motivated by the findings on market timing of Baker and Wurgler (2002) who argue that current capital structures are the result of past efforts to time the market, and DeAngelo, DeAngelo, and Stulz (2010) who describe market timing as 'the most prominent theoretical explanation for SEOs'. The market timing hypothesis predicts that managers will tend to rely more heavily on equity financing when they perceive that their stock is overpriced, and that as a result heavy reliance on debt financing will be associated with underpricing and positive future risk-adjusted stock returns. The market timing hypothesis has no particular implications for the relation between current debt financing and future profitability unless changes in future profitability are anticipated by managers but not by the market.

We find that, contrary to the prediction of the MT hypothesis, stocks of firms that rely more heavily on debt to finance their asset expansion have lower future risk adjusted returns which implies that their stock is more over-valued. Thus, not only does the MT hypothesis not explain our findings, it poses a further puzzle, of why firms issue more debt when their shares are overpriced.

The question is the more pressing in that debt issuance is most often regarded as a threat to managerial independence as the result of the need to service the debt out of free cash flow, the constraints imposed by bond covenants, debtholder monitoring and even bankruptcy. In addition, debt financing increases the risk of any stock held by the manager.

Our second hypothesis is more closely related to recent dynamic theories of corporate finance in that it combines the pecking order hypothesis of Myers (1984) with a precautionary financing 
motive. We label it the extended pecking order (EPO) hypothesis. Combining the precautionary motive with the pecking order hypothesis, a firm that faces a decline in future profitability will tend to raise more external finance and, since debt is the preferred type of external finance, a greater proportion of its total financing will be debt financing. This creates a link between the amount of debt financing and future declines in profitability. Note that, under the EPO hypothesis, the link between debt financing and future declines in profitability runs through external financing and, once account is taken of the amount of external financing that is raised, there is no reason to expect a marginal effect of expected future changes in profitability on the amount of debt financing. Contrary to this prediction, we continue to find a strong relation between the amount of debt financing and future changes in profitability after taking account of the amount of external financing. We also find that, contrary to the intuition that precautionary financing will forecast declines in future profitability, the amount of external financing is positively associated with the future change in the Return on Assets.

Our third hypothesis, the making the numbers (MTN) hypothesis, is that financing decisions are influenced by managerial incentives to meet earnings per share targets. In particular, since executive compensation schemes do not take explicit account of risk and most compensation contracts have option like features because of limited liability, a manager has an incentive to increase risk through leverage, and to 'roll the dice', when future prospects look relatively poor. The hypothesis is motivated by the survey evidence of Graham and Harvey (2001) that 'when issuing equity, respondents are concerned about earnings per share dilution and recent stock price appreciation.' It is also consistent with the evidence reported by Graham, Harvey, and Rajgopal (2005) that managers place a very high importance on earnings and not cash flows or other metrics.

Consistent with the making the numbers (MTN) hypothesis, we find that debt financing tends to increase the Return on Equity and therefore earnings per share for a given level of the Return on Assets; that holding constant total asset growth, debt issuance is positively associated with such measures of pressure on managers as over-optimistic analyst forecasts and over-valued stock, as well as poor past and current operating performance and worse future operating performance; and that debt issuance tends to be higher ceteris paribus when it has the most effect on earnings per share because the earnings yield is high relative to bond yields. Finally, managers of high debt issuing firms tend to be more recently appointed and to have shorter future tenures. 


\title{
Leaning against the Wind: \\ Debt Financing in the Face of Adversity
}

October 30,2015

Michael J. Brennan
Anderson School, University of California Los Angeles, Manchester Business School.

Holger Kraft

Goethe University, Faculty of Economics and Business Administration, Frankfurt am Main, Germany

\begin{abstract}
We offer evidence of a new stylized feature of corporate financing decisions: the tendency of managers to rely more on debt financing when earnings prospects are poor. We term this 'leaning against the wind' and consider three possible explanations: market timing, precautionary financing, and 'making the numbers'. We find no evidence in favor of the first two hypotheses, and provisionally accept the 'making the numbers' hypothesis that managers who are under pressure because of unrealistically optimistic earnings expectations by analysts and deteriorating real opportunities, will rely more heavily on debt financing to boost earnings per share and return on equity.
\end{abstract}

KEYWORDS: Capital structure, financing policy, managerial incentives

JEL-Classification: G12, G14, G32

Acknowledgements: We thank Thomas Dangl, Sheridan Titman and Harry DeAngelo as well as seminar participants at Bocconi University, Collegio Carlo Alberto, Cambridge University, the National University of Singapore and Wirtschaftsuniversitaet Vienna for helpful comments on a previous version of this paper which was circulated with the title Financing Asset Growth. Holger Kraft gratefully acknowledges financial support from Deutsche Forschungsgemeinschaft (DFG) and the Center of Excellence SAFE, funded by the State of Hessen initiative for research LOEWE. 


\title{
Leaning against the Wind: Debt Financing in the Face of Adversity
}

October 30, 2015

\begin{abstract}
We offer evidence of a new stylized feature of corporate financing decisions: the tendency of managers to rely more on debt financing when earnings prospects are poor. We term this 'leaning against the wind' and consider three possible explanations: market timing, precautionary financing, and 'making the numbers'. We find no evidence in favor of the first two hypotheses, and provisionally accept the 'making the numbers' hypothesis that managers who are under pressure because of unrealistically optimistic earnings expectations by analysts and deteriorating real opportunities, will rely more heavily on debt financing to boost earnings per share and return on equity.
\end{abstract}

KEYWORDS: Capital structure, financing policy, managerial incentives

JEL-Classification: G12, G14, G32 


\section{Introduction}

In recent years the failure of static theories of capital structure to explain observed capital structure decisions, and in particular their failure to explain the observed slow speed of adjustment to target capital structures, ${ }^{1}$ has lent support to a family of dynamic models of capital structure in which financing decisions depend not only on the current level of profitability and financial structure but also on expectations about future levels of profitability and financing needs.

In this paper we provide empirical evidence that financing decisions do depend on expectations about future profitability. We find that, after allowing for asset growth and mean reversion in profitability, debt financing has strong predictive power for future changes in profitability as measured by the Return on Assets. While asset growth and the total amount of external financing tend to be associated with higher future profitability, increased reliance on debt financing is associated with a lower future return on assets. Since the amount of debt financing is a managerial choice variable, this implies that managers have information about the change in future profitability at the time of the financing and choose to issue more debt when future earnings prospects are relatively poor. This behavior which we term 'leaning against the wind', appears to be inconsistent with the traditional static tax and bankruptcy model which would predict a decline in debt capacity and a corresponding decline in debt financing in these circumstances. The relation between debt financing and future changes in the Return on Equity is much weaker but in the same direction.

We consider three possible explanations for leaning against the wind: market timing, precautionary financing combined with pecking order financing, and 'making the numbers'.

The market timing (MT) hypothesis is motivated by the findings on market timing of Baker and Wurgler (2002) who argue that current capital structures are the result of past efforts to time the market, and DeAngelo, DeAngelo, and Stulz (2010) who describe market timing as 'the most prominent theoretical explanation for SEOs'. The market timing hypothesis predicts that managers will tend to rely more heavily on equity financing when they perceive that their stock is overpriced, and that as a result heavy reliance on debt financing will be associated with underpricing and positive future risk-adjusted stock returns. The market timing hypothesis has no particular implications for the relation between current debt financing and future profitability unless changes in future profitability are anticipated by managers but not by the market.

\footnotetext{
${ }^{1}$ For contrasting views on the importance of target capital structures see Flannery and Rangan (2006) and DeAngelo and Roll (2015).
} 
We find that, contrary to the prediction of the MT hypothesis, stocks of firms that rely more heavily on debt to finance their asset expansion have lower future risk adjusted returns which implies that their stock is more over-valued. Thus, not only does the MT hypothesis not explain our findings, it poses a further puzzle, of why firms issue more debt when their shares are overpriced. The question is the more pressing in that debt issuance is most often regarded as a threat to managerial independence as the result of the need to service the debt out of free cash flow, the constraints imposed by bond covenants, debtholder monitoring and even bankruptcy. In addition, debt financing increases the risk of any stock held by the manager. What then could make debt financing attractive to managers when the stock is overpriced?

Our second hypothesis is more closely related to recent dynamic theories of corporate finance in that it combines the pecking order hypothesis of Myers (1984) with a precautionary financing motive. We label it the extended pecking order (EPO) hypothesis. The precautionary financing motive is implied by dynamic capital structure models in which 'the firm is forward-looking, making current investment and financing decisions in anticipation of future financing needs. ${ }^{2}$ The precautionary motive implies that a firm that anticipates a decline in future profitability will find it advantageous to raise external finance immediately in the expectation that financing costs will be higher in the future. ${ }^{3}$ The pecking order hypothesis of Myers (1984) implies that when external finance is required firms will first raise debt financing and only turn to external equity when their ability to issue debt at reasonable cost is exhausted. Therefore, combining the precautionary motive with the pecking order hypothesis, a firm that faces a decline in future profitability will tend to raise more external finance and, since debt is the preferred type of external finance, a greater proportion of its total financing will be debt financing. This creates a link between the amount of debt financing and future declines in profitability. Note that, under the EPO hypothesis, the link between debt financing and future declines in profitability runs through external financing and, once account is taken of the amount of external financing that is raised, there is no reason to expect a marginal effect of expected future changes in profitability on the amount of debt financing. Contrary to this prediction, we continue to find a strong relation between the amount of debt financing and future changes in profitability after taking account of the amount of external financing. We also find that, contrary to the intuition that precautionary financing will forecast declines in future profitability, the amount of external financing is positively associated with

\footnotetext{
${ }^{2}$ Hennessy and Whited (2005).

${ }^{3}$ Leary and Roberts (2010) show that when the gap between anticipated capital expenditures and internal funds is large firms issue debt and, to a lesser extent, equity.
} 
the future change in the Return on Assets.

Our third hypothesis, the making the numbers $(M T N)$ hypothesis, is that financing decisions are influenced by managerial incentives to meet earnings per share targets. In particular, since executive compensation schemes do not take explicit account of risk and most compensation contracts have option like features because of limited liability, a manager has an incentive to increase risk through leverage, and to 'roll the dice', when future prospects look relatively poor. The hypothesis is motivated by the survey evidence of Graham and Harvey (2001) that 'when issuing equity, respondents are concerned about earnings per share dilution and recent stock price appreciation. ${ }^{4}$ It is also consistent with the evidence reported by Graham, Harvey, and Rajgopal (2005) that managers place a very high importance on earnings and not cash flows or other metrics. ${ }^{5}$ The $M T N$ hypothesis is also motivated by the suspicion aroused by public discussions about bank capital following the financial crisis, that managers do not accept the Modigiliani-Miller framework and believe instead that equity is more expensive than debt which leads them to rely more on debt financing when the future returns on investments are expected to be low in order to achieve their target earnings per share and return on equity targets. ${ }^{6}$ Unlike behavioral models of corporate finance, ${ }^{7}$ the $M T N$ hypothesis does not presume irrationality on the part of either investors or managers. Rather it assumes that managers

\footnotetext{
${ }^{4}$ They also find 'very little evidence that executives are concerned about asset substitution, asymmetric information, transactions costs, free cash flows, or personal taxes.'

${ }^{5}$ 'Our results indicate that CFOs believe that earnings, not cash flows, are the key metric considered by outsiders. The two most important earnings benchmarks are quarterly earnings for the same quarter last year and the analyst consensus estimate. Meeting or exceeding benchmarks is very important. Managers describe a trade-off between the short-term need to deliver earnings and the long-term objective of making value-maximizing investment decisions. Executives believe that hitting earnings benchmarks builds credibility with the market and helps to maintain or increase their firms stock price.' They also report that 'Second, managers are interested in meeting or beating earnings benchmarks primarily to influence stock prices and their own welfare via career concerns and external reputation, and less so in response to incentives related to debt covenants, credit ratings, political visibility, and employee bonuses that have traditionally been the the focus of academic work.'

Matsunaga and Park (2001) find that failure to meet analysts consensus estimates results in paycuts for the CEO.

${ }^{6}$ For example the Chairman of Deutsche Bank, Josef Ackermann (2010) was quoted as saying that 'Demands for Tier-1 capital ratio of $20 \%$ [...] could depress ROE to levels that make investment into the banking sector unattractive relative to other business sectors.'

${ }^{7}$ For a survey see Baker, Ruback, and Wurgler (2007).
} 
are rational but that at least a part of managerial compensation depends on observable accounting variables and that managers rationally take account of this in making decisions.

Consistent with the making the numbers $(M T N)$ hypothesis, we find that debt financing tends to increase the Return on Equity and therefore earnings per share for a given level of the Return on Assets; that holding constant total asset growth, debt issuance is positively associated with such measures of pressure on managers as over-optimistic analyst forecasts and over-valued stock, as well as poor past and current operating performance and worse future operating performance; and that debt issuance tends to be higher ceteris paribus when it has the most effect on earnings per share because the earnings yield is high relative to bond yields. Finally, managers of high debt issuing firms tend to be more recently appointed and to have shorter future tenures.

Our findings have implications for the controversial issue of corporate capital structure. We take the view advanced by Myers (1984) and Baker and Wurgler (2002) that corporate capital structures are the result of past financing decisions, so that the best way to understand current capital structures is to analyze the financing decisions that gave rise to them. Our main contribution is to provide empirical evidence of a link between corporate financing decisions and managerial incentives, ${ }^{8}$ and to show how this link provides an explanation for the poor returns that are realized by firms that rely heavily on debt to finance their asset growth. We do not claim that this is the whole story of financing decisions. Undoubtedly, other considerations also are at work. As Myers (2002) remarks 'There is no universal theory of capital structure, and no reason to expect one [...] Each factor could be dominant for some firms or in some circumstances, yet unimportant elsewhere.'

Therefore, given that the empirical evidence is inconsistent with the first two hypotheses, we provisionally accept the making the numbers hypothesis which predicts that managers who are under pressure because of unrealistically optimistic earnings expectations by analysts and deteriorating real opportunities, will rely more heavily on debt financing in order to boost earnings per share and the return on equity.

The paper is organized as follows. In Section 2 we present the basic evidence of 'leaning against the wind' behavior. Section 3 develops empirical predictions from the three basic hypotheses. Section 4 describes related literature. Section 5 describes the data. Section 6 is concerned with the extended pecking order hypothesis. Section 7 shows that debt financing tends to raise the Return on Equity for a given Return on Assets. Section 8 presents evidence of over-valuation associated with debt financing.

\footnotetext{
${ }^{8}$ Welch (2004) writes, 'corporate issuing motives themselves remain largely a mystery.'
} 
Section 9 shows that greater reliance on debt financing is associated with several measures of pressure on managers, and shows that future changes in profitability remain a significant determinant of reliance on debt financing after allowing for other factors.

\section{Leaning against the Wind}

In Table 1 we report evidence that financing decisions reflect information about future changes in profitability. Each year from 1968 to 2010 we calculate the changes from year $y$ to year $y+1$ in Return on Assets, $\Delta R O A_{y+1}$, and Return on Equity, $\Delta R O E_{y+1}$, and regress these changes in profitability on the corresponding lagged measure of profitability, and three variables that reflect financing choices in year $y . D I_{y}$ is the net amount of debt issued in year $y$ normalized by the beginning of year assets. $T A G_{y}$ is the Total Asset Growth in year $y$, so that the difference between $T A G_{y}$ and $D I_{y}$ is the amount of asset growth that is financed by non-debt sources of funds. Finally, $(D I+S I)_{y}$ is the total amount of external financing in year $y$ as measured by the increase in equity outstanding and debt outstanding, both normalized by beginning of year assets. ${ }^{9}$

The table reports the results of panel regressions with firm fixed effects. Regressions (i) and (ii) show that $R O A$ is strongly mean reverting - approximately one half of the deviation of the variable from its long run mean is eliminated in one year. In addition, the increase in profitability is positively associated with firm growth in year $y$, as measured by Total Asset Growth, $T A G_{y}$, or, less strongly, by the normalized amount of external financing, $(D I+S I)_{y}$. This is unexpected in that it contrasts with Titman, Wei, and Xie (2004) and Cooper, Gulen, and Schill (2008) who find that higher asset growth is associated with lower subsequent stock returns. Most significantly, we see that debt issuance in year $y, D I_{y}$, is strongly negatively associated with the change in profitability from year $y$ to year $y+1$ : the coefficient of $D I_{y}$ is significant at the $1 \%$ level. The results in column (ii) which include both total external financing, $(D I+S I)_{y}$, and debt financing, $D I_{y}$, contrast with those of Bradshaw, Richardson, and Sloan (2006). While our results imply a positive effect of equity financing, and a negative effect of debt financing on future profitability, they find that equity issuance has a greater negative effect on future profitability than does debt issuance. The reason for their results appears to be that they do not take account of firm fixed effects that allow for firm-specific long-run profitability and target debt ratios. ${ }^{10}$ Columns (iii) and (iv) report similar regressions in which the measure of

\footnotetext{
${ }^{9}$ Detailed definitions of the variables are given in Section 5 .

${ }^{10} \mathrm{It}$ is important to include firm fixed effects in the regression because of the importance of unobserved firm
} 
profitability is the Return on Equity. While $R O E$ shows even stronger mean reversion, $\triangle R O E_{y+1}$ is much less strongly related to the financing variables. Indeed, when firm growth is measured by the external financing variable, $(D I+S I)_{y}$, the debt financing variable is insignificant, and is only marginally significant in regression (iii). We note that, while $\triangle R O A$ is not affected by the financing decisions, $\triangle R O E$ is directly affected by the leverage change implied by $D I_{y}$. It is possible therefore that the relative lack of predictive power of $D I_{y}$ for $\triangle R O E$ is due to the fact that leverage decisions are made to offset the effect of the change in $R O A$ on $R O E$. We shall investigate this.

At this point we emphasize the results of regressions (i) and (ii), which show that debt issuance is associated with a decline in future fundamental profitability, $R O A$, after allowing for Total Asset Growth or Total External Financing. We refer to this as 'leaning against the wind' because it is consistent with this possibility of offsetting the effect of a decline in fundamental profitability, $\triangle R O A$, on the Return on Equity, ROE, by an increase in leverage. In the following section we discuss testable implications of three hypotheses for this relation between debt financing and future profitability.

\section{Hypotheses}

We consider three alternative hypotheses that could explain the negative relation between reliance on debt financing for a given level of asset growth and the future change in operating profitability: market timing, making the numbers, and extended pecking order.

Market Timing The idea that firms might determine their choice of financing instruments according to their valuations and market conditions has a long history, starting with Baxter and Cragg (1970) and Marsh (1982). If a firm is overpriced by the capital markets for some reason, then the common stock is proportionately more overpriced than the whole firm, and more overpriced than the debt issued by the firm. This follows from the well known observation that the elasticity of an option (stock) price with respect to the underlying stock (firm value) exceeds unity. Therefore, if a firm that is overpriced issues debt, then the subsequent fall in its stock price when the firm over-valuation is corrected will be greater than if the firm had issued equity. As a result, a firm that finances itself with debt rather than equity when the equity is overpriced and when it is able to issue equity is heterogeneity for firm financing decisions. See Flannery and Rangan (2006) and Lemmon, Roberts, and Zender (2008). 
failing to act in the interests of its current shareholders. It is also possible that the equity of a firm is overpriced while the whole firm is correctly valued; for example, the relative pricing of the debt and equity might rest on an incorrect assessment of future risk. In this case the debt would be underpriced and therefore the costs of issuing debt rather than equity would be greater than in the case in which the equity is overpriced by the same amount because the firm as a whole is overpriced. Thus, insofar as managerial interests are aligned with those of shareholders, managers have an incentive to issue equity rather than debt when the stock is over-valued, and to issue debt rather than equity when the stock is under-valued, and the market timing hypothesis predicts that firms will rely more heavily on debt financing when the stock is under-valued and rely less heavily on debt financing when the stock is over-valued.

The hypothesis finds support in the survey evidence of Graham and Harvey (2001), Table 8, who report that CFO's claim that 'the amount by which our stock is under-valued or over-valued was an important or very important consideration' in issuing equity. Baker and Wurgler (2002) find that current capital structures of individual firms are strongly influenced by market conditions and valuations at the times when these firms raised finance; they report that market timing has large persistent effects of corporate capital structures and in Baker and Wurgler (2000) they find that the aggregate share of equity issues in new financing has predictive power for future stock returns. It is possible then that firms that anticipate declining profitability in the future also believe that the market has become overly pessimistic so that their stock is under-valued, and therefore rely more heavily on debt financing. This would create a negative association between debt issuance in year $y$ and future change in profitability such as we observe in Table 1 . If this is so, then we would expect heavy reliance on debt financing to be followed by bigger risk adjusted stock returns, and to be associated with excessively pessimistic analyst forecasts.

Therefore we propose the following two empirical predictions of market timing:

MT1: Heavy reliance on debt financing forecasts positive risk-adjusted stock returns.

MT2: Heavy reliance on debt financing is associated with over-pessimistic analyst forecasts.

Making the Numbers The basic idea of the making the numbers hypothesis is that reported earnings are a major concern for managers, who therefore take account of the effect of financing decisions on reported earnings, and rely more heavily on debt to finance their asset growth when they 
are under pressure and debt finance will tend to raise earnings per share. ${ }^{11}$ The making the numbers hypothesis does not imply that managers are concerned exclusively with reported earnings; their stock ownership and compensation packages typically give them strong incentives to be concerned also with the share price. However, when performance has been poor and managerial tenure is uncertain, or when managers realize that future performance will disappoint investor expectations, managers will be under the strongest pressure to perform. It is at such times that we expect the 'making the numbers' motive to be strongest. A necessary condition for pressure on managers to lead to increased debt financing is that debt financing raises earnings per share or the Return on Equity for a given level of fundamental profitability. To the extent that the making the numbers motive is strongest when managers are faced with the problem of excessively optimistic investor expectations, the $M T N$ hypothesis implies that heavy reliance on debt financing will be associated with excessively optimistic analyst forecasts and with future stock price declines. When the cost of debt is less than the earnings-price ratio, debt financing will tend to raise reported earnings per share, making debt financing especially attractive to managers under these conditions.

We propose the following empirical predictions:

MTN1: Heavy reliance on debt financing forecasts a decline in profitability as measured by the Return on Assets.

MTN2: Debt financing tends to raise the Return on Equity for a given Return on Assets.

MTN3: Heavy reliance on debt financing is associated with over-optimistic analyst forecasts.

MTN4: Heavy reliance on debt financing forecasts negative risk-adjusted stock returns.

MTN5: High earnings yield (relative to the bond rate) forecasts more reliance on debt financing.

MTN6: Heavy reliance on debt financing is associated with measures of pressure on managers.

MTN1 is of course consistent with the evidence that we saw in column (i) of Table 1. We shall assess the validity of the other predictions in subsequent sections

Extended Pecking Order In the Graham and Harvey (2001) survey managers rated financial flexibility at the top of their list of important factors in determining debt policy. A firm that is facing a deteriorating profit environment may well decide to raise finance today anticipating that it will only be able to raise finance in the future on less advantageous terms. This gives rise to what we label a

\footnotetext{
${ }^{11}$ Earnings per share dilution was the most commonly cited factor that was important influencing stock issuance decisions by Graham and Harvey (2001), Table 8.
} 
precautionary demand for external finance. The precautionary finance motive will lead to a negative association between external finance this year and future changes in profitability as measured by the Return on Assets. The pecking order model of Myers (1984) predicts that firms will issue debt in preference to equity whenever they can, so that external financing will for the most part be debt financing. Combining the precautionary finance motive with the pecking order model leads to an extended pecking order hypothesis which predicts that there will be a negative relation between the amount of debt financing and future declines in profitability. Note however, that the relation is induced entirely by the external financing link - precautionary finance leads to external finance, and external finance tends to mean debt finance. Therefore, the extended pecking order hypothesis predicts that there will be no relation between debt financing and future changes in profitability once account is taken of net external financing.

The extended pecking order hypothesis leads to the following empirical implications:

EPO1: Heavy reliance on external financing is associated with future declines in future profitability (precautionary motive).

EPO2: There is no relation between reliance on debt financing and future changes in profitability once account is taken of net external financing.

\section{Related Literature}

In addition to the extensive studies of stock returns following the issuance of stock and bonds that bear on market timing, this study is related to dynamic structural models of the firm that link financing decisions to expectations about future financing needs and profitability. Models such as Brennan and Schwartz (1984), Hennessy and Whited (2005), Gamba and Triantis (2008), and DeAngelo, DeAngelo, and Whited (2011) rely on debt overhang, financing costs, and tax benefits of debt to create an intertemporal link between corporate financing, payout, and investment policies. This is reflected in our extended pecking order hypothesis in which firms issue debt this year to finance investment the following year when financing conditions are expected to be more difficult.

The making the numbers hypothesis is related to models such as Stulz (1990) which relates corporate capital structures to managerial incentives, and Zwiebel (1996), Morellec (2004) and Lambrecht and Myers (2008) which also recognize the discretionary role of management and focus on the conflict of interest between managers and shareholders. There is relatively little empirical work relating 
managerial incentives to corporate financing decisions. The early evidence on the relation between managerial ownership and leverage is mixed. Friend and Lang (1988) and Firth (1995) find a negative relation between executive ownership and leverage which they attribute to managerial risk aversion. On the other hand, Mehran (1992) reports a positive relationship between the firm's leverage ratio and the percentage of executives' total compensation in incentive plans, and the percentage of equity owned by managers. Berger, Ofek, and Yermack (1997) report that entrenched CEO's tend to avoid debt and that leverage increases after involuntary CEO replacements. However, they also find that leverage is positively associated with CEO stock and option ownership. More recently, Frank and Goyal (2007) have found a significant role for CEO characteristics and incentives in capital structure decisions: they report that leverage is negatively related to the CEO's pay-for-performance sensitivity. Similarly, Birkeland, Eriksen, and Ueland (2011) report that the leverage of Nordic firms is negatively related to managerial holdings of both stock and options. However, these studies are plagued with endogeneity problems and, as Welch (2011) remarks, 'although the (empirical) literature has uncovered some forces that contribute on the margin to explaining managerial capital structure activity, the firstorder managerial motives still remain largely a mystery.' Jung, Kim, and Stulz (1996) show that stock price reactions to equity issues depend positively on the firm's growth opportunities as measured by the market-to-book ratio; they argue that firms that issue equity, when they are predicted by a logit model to issue debt, do so in order to expand managerial discretion to make unprofitable investments that offer private benefits to managers. Although not directly comparable, this is somewhat in contrast to our finding that firms that rely most heavily on debt financing have worse future operating profit. Our findings that asset and debt growth predict future stock returns are consistent with the evidence of Titman, Wei, and Xie (2004) and Cooper, Gulen, and Schill (2008), as well as with the evidence that capital raising activities, such as issues of stock or debt, lead to lower future returns, while returns of capital to investors through share repurchases or debt retirements are associated with higher future stock returns. ${ }^{12}$ Our paper builds on these results by exploring the motives of managers for choosing particular financing mixes for a given asset growth rate and relating the motives of managers to the abnormal returns that are observed. Our focus on firms' financing choices is related to the extensive literature concerning the choice between bond and stock issuance. ${ }^{13}$ A significant difference between

\footnotetext{
${ }^{12}$ Fama and French (2008) argue that 'there is no asset growth anomaly in the average returns on the big stocks that account for more than $90 \%$ of total market cap.' Daniel and Titman (2006) find that future returns are strongly negatively related to growth that is financed by stock issuance.

${ }^{13}$ See for example Baxter and Cragg (1970), Marsh (1982), Jung, Kim, and Stulz (1996), Leary and Roberts
} 
our approach and that of these papers is that we consider all types of debt financing while most of these papers focus on predicting which firms will issue bonds and which will issue stock, and implicitly ignore the possibility that the equity issuer may be simultaneously borrowing from the bank, and the debt issuer may be repaying bank debt.

Our findings are also related to an extensive accounting literature that documents the manipulation of corporate earnings either through accruals or by changes to real activities. The surveys of Bruns and Merchant (1990) and Graham, Harvey, and Rajgopal (2005) report a greater willingness on the part of managers to manipulate earnings through real activities than through accruals, even though the latter imposes real economic costs; and the tendency of firms to prune R\&D expenditure to meet earnings targets is well attested. ${ }^{14}$ Interestingly, Liu, Ning, and Davidson (2010) provide evidence that firms manipulate earnings through discretionary accruals in the year of, and the year prior to, a bond issue. This paper is perhaps closest to Bradshaw, Richardson, and Sloan (2006) which reports many related results. The principal distinction between their results and ours is that they do not allow for unobserved firm characteristics in their regressions relating financing choices to subsequent changes in profitability. As a result their results are sometimes at apparent odds with ours. For example, they find ( $\mathrm{p}$ 54) a 'negative relation between net external financing and future profitability (which) $[\ldots]$ is stronger for equity financing (than for debt financing)'. We find on the other hand that, holding constant total asset growth or total external financing, there is a strong negative relation between debt financing and future profitability. They conclude ( $\mathrm{p} 55$ ) that 'firms time their corporate financing activities to exploit the temporary misvaluation of their securities.' Our main point is the puzzle that is presented by firms failing to exploit misvaluation of their securities since we find that, instead of issuing more stock when it is over-valued, they rely more heavily on debt financing when their stock is over-valued.

\section{Data}

Our main data source is the merged Compustat-CRSP data set. We restrict our analysis to firms with fiscal year ending in December, starting in 1968, ignoring non-financial firms with SIC codes 6000 and 6999. To mitigate back-filling biases we disregard the first year's observation for each firm.

(2010).

${ }^{14}$ Baber, Fairfield, and Haggard (1991), Deechow and Sloan (1991), Bushee (1998). 
We combine annual accounting data for the years 1968 to 2010 with stock return data for 1966 to 2011. We match 85,597 out of the 87,803 accounting data observations with stock return data. The number of sample firms with both accounting and stock return data ranges from 843 in 1968 to 2,529 in 2009 and averages 2,038. We also use the IBES data on analyst earnings forecasts for 1975 to 2010 and Execcomp data from Compustat from 1992 to 2010 for information about CEO appointments, compensation and exits.

Our primary variables of interest are:

Total Asset Growth (TAG): The proportionate change in the book value of the firm's total assets during the year.

Debt Growth (DI): The change in the book value of all short and long term debt outstanding (excluding accounts payable) expressed as a proportion of the book value of the firm's assets at the beginning of the year. (Debt is defined as the sum of Compustat codes dlc and dltt.) ${ }^{15}$

Stock Growth (SI): The change in the book value of all stock financing expressed as a proportion of the book value of the firm's assets at the beginning of the year. Stock financing is defined as preferred stock (Compustat code: pstk) plus common equity (Compustat code: ceq) plus minority interest (Compustat code: mib) minus retained earnings (Compustat code: re).

Return on Assets (ROA): Operating income after depreciation (Compustat code: oiadp) divided by the lagged book value of assets (Compustat code: at).

Return on Equity (ROE): Income before extraordinary items (Compustat code: ib) divided by the lagged book value of equity (Compustat code: ceq).

Market to Book Ratio $(M / B)$ : Number of shares (Compustat code: csho) multiplied by end-of-year share price (Compustat code: prcc_f) divided by book value of equity (Compustat code: ceq).

Earnings forecast errors $(F E)$ : The scaled median analyst forecast errors for the year. We denote by $F E(j, k)$ the forecast error for year $k$ made in the last quarter of year $j$; the forecast errors are scaled by the stock price at the end of the year in which they are made. The median forecast errors are taken from IBES.

\footnotetext{
${ }^{15}$ Welch (2011) objects to the use of the ratio of financial debt to assets as a measure of firm leverage, but admits that 'A universal best measure may not even exist, but might depend on the question being asked.' Our definition is motivated by the finding that future abnormal stock returns are associated with this measure, and by the fact that increases in financial debt are the result of managerial decisions whereas the behavior of other components of the liabilities may be beyond direct managerial control in a given year.
} 
CEO turnover (CEOstart): A dummy variable that is equal to unity if a new CEO is appointed. Data are taken from Execcomp from 1992 to 2012.

Stock price sensitivity (SENSI): The sensitivity of the CEO's wealth to the stock price is calculated as the product of the share price and the sum of the number of shares and one half the number of unexercised options held by the CEO. The sensitivity is normalized by the CEO's base salary. These data are from Execcomp for 1992 to 2010.

Average corporate bond yield (Baa): The annual average of weekly observations for the year on Moody's Seasoned Baa Corporate Bond Yield.

\section{External Financing, Debt Issuance and Profitability Changes}

Table 1 allows us to address the two implications of the extended pecking order hypothesis. Regression (ii) leads to a rejection of both EPO1 and EPO2. First, net external financing, $(D I+S I)_{y}$ is positively, and not negatively, associated with the future change in profitability as the precautionary motive implies, although the relation is not strong $(t=2.57)$. Secondly, debt financing, $D I_{y}$, remains strongly negatively associated with the future change in profitability after allowing for the effect of external financing.

\section{$7 \quad$ The Effect of Debt Financing on Return on Equity}

The $M T N$ hypothesis relies on the assumption that managers are able to raise the expected value of the Return on Equity by relying more heavily on debt financing. We have therefore stated MTN2 as an implication of the $M T N$ hypothesis: Debt financing tends to raise the Return on Equity for a given Return on Assets. To test this implication we estimate panel regressions for the years 19682010 in which the dependent variable is the change in Return on Equity from year $y$ to year $y+1$, $\triangle R O E_{y+1}$, and the independent variables are the corresponding change in the Return on Assets, $\Delta R O A_{y+1}$, the normalized debt issuance in year $y, D I_{y}$, and control variables. Several different regression specifications are considered and the results are reported in Table 2.

In regression (i) there are no control variables; the coefficients of both $\Delta R O A_{y+1}$ and $D I_{y}$ are sig- 
nificant at the $1 \%$ level. More importantly, the coefficient of $D I_{y}$ is positive so that, consistent with $M T N 2$, debt issuance tends to raise the change in Return on Equity for a given change in the Return on Assets. The coefficient remains positive and highly significant as we control for the debt ratio, $(D / A)_{y}$, and the asset growth rate, $T A G_{y}$ in regressions (ii) and (iii). In regressions (iv) and (v) we include as an independent variable $(A / E Q)_{y} \times \Delta R O A_{y+1}$, the leverage adjusted change in the Return on Assets, where $A$ is Total Assets and $E Q$ is Total Equity at the beginning of year $y$ : this is the predicted change in the Return on Equity if the debt ratio remains constant. The coefficient of $D I_{y}$ remains highly significant and its point estimate increases relative to the other specifications. In specification (vi) we allow for different responses of $\Delta R O E_{y+1}$ to $\triangle R O A_{y+1}$ and $D I_{y}$ according to the sign of $\Delta R O A_{y+1}$; while the point estimates of the coefficients are slightly different depending on the sign of $\triangle R O A_{y+1}$, they do not change our basic conclusion that, as stated in $M T N 2$, debt issuance tends to lead to an increase in the Return on Equity for a given change in the Return on Assets.

\section{Debt Financing and Evidence of Overvaluation}

The market timing hypothesis implies that firms will rely more heavily on debt financing when their stock is under-valued. On the other hand, the making the numbers hypothesis suggests that to the extent that managers are using debt financing in an attempt to conceal bad news about profitability from investors, debt financing will be associated with over-valuation of the stock and subsequent negative risk-adjusted returns as investors become aware of the true situation. To assess whether debt financing is associated with over-valuation or under-valuation we examine both the future risk adjusted returns on portfolios formed on the basis of asset growth and debt financing, and the behavior of analyst forecast errors around debt issuance. We also relate the abnormal returns to the realization of the forecast errors.

We start by examining the characteristics of portfolios that are formed by sorting firms according to both Total Asset Growth $(T A G)$ and debt growth as a proportion of assets $(D I)$. Each year $y$, from 1968 to 2010, 10 portfolios are formed on the basis of the firm's $T A G$ during the year. Then each of the 10 portfolios formed on the basis of $T A G$ is subdivided into 4 sub-portfolios on the basis of $D I_{y}$, the change in debt outstanding during year $y$ expressed as a proportion of the book value of assets at the beginning of the year; only firms with positive changes in debt outstanding, 'debt issuers' are included. DI1 is the subportfolio with the smallest relative increase in debt and DI4 the portfolio 
with the largest debt increase.

\subsection{Portfolio Characteristics}

Summary statistics based on equally weighted firm characteristics for the portfolios in the year of portfolio formation are presented in Table 3. Panel A shows that the assets of the first three TAG deciles actually shrink on average, and it is only in the deciles above the fourth that the asset growth rate is above $5 \% .{ }^{16}$ TAG decile 1 has average asset growth rates of around $-30 \%$, implying significant asset disposals or write-downs. For $T A G$ decile 2 the average growth rate is of the order of $-10 \%$ and for decile 3 of $-3 \%$. The remaining deciles have modest but positive growth rates in the range of 1-9\%. Deciles 7, 8 and 9 are high growth deciles with growth rates of around $12 \%, 18 \%$, and $32 \%$ respectively. Decile 10 contains hyper growth firms in which the average growth rates range from $75 \%$ to $303 \%$.

Panel $\mathrm{B}$ shows that debt growth rates are mainly below $10 \%$ of assets except in the highest debt issuance quartile where they range up to $150 \%$ in the highest $T A G$ decile. Not surprisingly, equity growth is increasing in asset growth and decreasing in debt growth.

Panel D shows that there is a negative relation between debt issuance and firm size for a given asset growth decile, so that smaller firms are inclined to rely more heavily on debt to finance a given asset growth rate, despite prior evidence that large firms tend to have higher debt ratios than small firms. ${ }^{17}$ Firm size and total equity are increasing functions of the asset growth decile up to about the $7^{\text {th }}$ decile, and is thereafter decreasing. The average number of firms in each portfolio tends to increase with the asset growth rate reflecting the increased tendency of growing firms to issue new debt.

\subsection{Returns}

Define month 0 as the December of year $y$, the year in which $T A G$ is measured. Then, for each portfolio formation year $y$, equally weighted (EW) and value weighted (VW) portfolios are formed at the beginning of month 7 , July of year $y+1$, are held until the end of month 18, and are not rebalanced during this time window. In this way a time series of portfolio returns is formed for each

\footnotetext{
${ }^{16}$ In subsequent tables we leave a space after $T A G$ decile 3 to remind the reader that the first three deciles have negative average asset growth.

${ }^{17}$ See Titman and Wessels (1988), Frank and Goyal (2009).
} 
portfolio for the time window $[7,18]$.

The Fama and French (1992) three factor model is used to calculate abnormal returns on each of the portfolios by estimating the following regression:

$$
R_{p, \tau}-R_{F, \tau}=\alpha_{p}+\beta_{p}^{M}\left(R_{M, \tau}-R_{F, \tau}\right)+\beta_{p}^{H M L} H M L_{\tau}+\beta_{p}^{S M B} S M B_{\tau}+\epsilon_{p \tau},
$$

where $R_{p, \tau}$ is the return on portfolio $p$ in month $\tau, R_{F, \tau}$ is the risk-free interest rate in month $\tau, R_{M, \tau}$ is the return on the market portfolio, and $H M L_{\tau}$ and $S M B_{\tau}$ are the returns on the Fama-French book-to-market and size factors, and $\alpha_{p}$ is the abnormal or risk-adjusted return on portfolio $p$. The regression is estimated using the whole sample of window $[7,18]$ returns. By using only returns in the post-financing period we avoid measurement problems due to changes in risk associated with the asset growth and financing. ${ }^{18}$

Table 4 reports the abnormal returns on the Total Asset Growth and Debt Issuance portfolios for months [7-18]. The most significant abnormal returns are for TAG10, the high asset growth portfolios and, consistent with prior findings, ${ }^{19}$ these are negative. In addition to the significant returns in TAG10, we note also that there are strong abnormal return effects associated with debt growth. The abnormal return in months $[7,18]$ on the high debt issuance quartile, $D I 4$, is less than or equal to that of the the low debt issuance quartile, $D I 1$, for virtually every $T A G$ decile. The average difference between the returns on the DI4 and DI1 quartiles across TAG deciles is minus 28 and 43 basis points per month or about $3.5 \%$ and $5 \%$ per annum for the VV and EW portfolios respectively. Only three (one) out of ten of the returns in DI4 are positive for the VW (EW) portfolios, while only two out of ten of the returns in $D I 1$ are negative (and three of them are positive and significant) for the EW portfolios; and for the VW portfolios the only return in $D I 1$ that is negative is in $T A G 10$. High debt issuance tends to be associated with negative returns while first quartile debt issuance tends to be associated with positive returns except in the highest asset growth deciles: the difference between the returns on debt issuance quartiles 4 and 1 is negative for all $\mathrm{EW} T A G$ deciles and for eight of the VW $T A G$ deciles.

\footnotetext{
${ }^{18}$ There is an extensive theoretical literature arguing that systematic risk will fall following periods of high investment. See for example Berk, Green, and Naik (1999) and Carlson, Fisher, and Giammarino (2004). Cooper and Priestley (2011) show that systematic risk as measured by Chen, Roll, and Ross (1986) decreases following high asset growth.

${ }^{19}$ See for example Titman, Wei, and Xie (2004) and Cooper, Gulen, and Schill (2008).
} 
The return patterns that we have described for months [7-18] continue in an attenuated form for months [19-30] (not reported): for the EW portfolios all but two of the high debt issuance portfolios in DI4 continue to have negative returns, and in TAG10 there are significant negative abnormal returns for the debt issuing portfolios, reaching minus 50 basis points per month for the high debt issuance portfolio.

The general pattern of post-announcement returns can be summarized as follows: abnormal returns for months [7-18] tend to be negative for high debt issuers and positive for low debt issuers, and abnormal returns are decreasing in asset growth and tend to be negative for the highest one or two asset growth deciles.

The importance of debt issuance relative to asset growth for future abnormal returns is substantiated by regression analysis. Table 5 reports the results of panel regressions of the abnormal returns for months 7-18 for the 40 asset growth/debt issuance portfolios on the logarithms of asset growth and debt issuance. ${ }^{20}$ In regression (i) the first variable is $\ln (1+T A G)$, the $\log$ of one plus the simple asset growth rate and all portfolios are included each year; in regression (ii) the first variable is the log of the simple asset growth rate and portfolios with negative average growth rates in a given year are omitted. The results are striking. The coefficients of both asset growth and debt issuance variables are negative, but only the coefficients of debt issuance are statistically significant, and this is despite the fact that the portfolios were formed by sorting first on asset growth and then on debt growth. Regression (ii) provides the higher explanatory power and, as one would expect, the results are more highly significant for the equally weighted portfolios shown in Panel $\mathrm{B}$, where the $t-$ statistic on $\ln (D I)$ is close to five for regression (ii) which explains $7 \%$ of the abnormal returns. This is strong evidence that firms that rely more heavily on debt to finance their asset growth tend to have more overpriced stock. This is contrary to prediction $M T 1$ of the market timing hypothesis, but is consistent with prediction MTN4 of the making the numbers hypothesis.

\subsubsection{Abnormal Returns and Changes in Fundamentals and Expectations}

To assess whether the abnormal returns in months [7-18] are related to news about fundamentals that is released during this time period, the average monthly abnormal returns on the 40 portfolios in year

\footnotetext{
${ }^{20}$ We use the abnormal returns of the portfolios, rather than computing abnormal returns of individual firms because of the difficulties of arising from changing betas for firms with strong asset asset growth and changing capital structures. See footnote 13.
} 
$y+1$ are regressed on the average changes in Return on Assets and Return on Equity of the firms in the portfolios between years $y$ and $y+1\left(\Delta R O A_{y+1}, \Delta R O E_{y+1}\right)$, as well as on the average scaled error in the median analyst forecast of earnings per share for year $y+1$ that is made in the last quarter of year $y, F E(y, y+1)$. The scaling is by the stock price at the end of the year. ${ }^{21}$ Note that all three variables become known during months [7-18].

The results of panel regressions are reported in Table 6. First, we note that the regression results are stronger for the EW portfolios than for the VW portfolios. Secondly, the abnormal return is significantly associated with the change in Return on Equity for both VW and EW portfolios, and for the EW portfolios the change in $R O E$ has a much stronger effect on abnormal returns than does the change in $R O A$ : the $t$-statistic of the former is less than three while on the latter it is in excess of six; when the changes in $R O A$ and $R O E$ are both included in the regression, for the VW portfolios neither variable remains significant, but for the EW portfolios only the change in $R O E$ is significant. Thus it appears that, at least for the smaller firms that dominate the EW regressions, investors are more concerned about the change in fundamentals that is represented in the Return on Equity than they are about the change in Return on Assets. This is surprising since the change in Return on Equity is the resultant of both the change in Return on Assets and the change in leverage: changes in the Return on Equity that are the product of changes in leverage are apparently not discounted by investors. This is at odds with the predictions of the Modigliani-Miller theorem, but is consistent both with the 'bankers' view' that what is important to investors is the Return on Equity, and with the belief of CFOs reported by Graham, Harvey, and Rajgopal (2005) that (equity) earnings are the key metric considered by investors.

In column (iii) the independent variable is the (average for the portfolio of the) median forecast error for year $y+1$ earnings per share for forecasts made in the last quarter of year $y$ scaled by the share price at the end of year $y$. Despite the shorter sample period necessitated by the availability of earnings forecast data, for both equal-weighted and value weighted portfolios the abnormal returns are negatively and significantly associated with the forecast errors.

Thus, it seems that the significant future abnormal returns for debt issuers that we observe in Table 4 and the regression results in Table 5 can be attributed, at least in part, to the failure of the market to make unbiased forecasts of future changes in $R O A, R O E$ and earnings per share. Table 7 reports for the 40 portfolios the equal and value weighted averages of the median analyst forecast errors for year

\footnotetext{
${ }^{21}$ See Christie (1987).
} 
$y+1$ earnings scaled by the share price at the end of year $y$ or $y-1$. Panel A refers to forecasts made at the end of year $y-1$ and Panel B to forecasts made at the end of year $y$. For every asset growth category, for both equal weighted and value weighted portfolios, and for forecasts made in both year $y-1$ and year $y$, the forecast error for the high debt issuance portfolio, DI4 exceeds that for the low debt issuance portfolio, DI1. This is evidence that analysts are relatively over-optimistic about the earnings prospects of firms that issue a large amount of debt in year $y$, both before the debt is issued, at the end of year $y-1$, and after debt is issued at the end of year $y$. This is consistent with prediction MTN3 and with our earlier conclusion that the stock of the high debt issuing firms is over-valued. It is inconsistent with prediction $M T 2$ of the market timing hypothesis. Table 8 reports the results of panel regressions of the individual firm scaled earnings forecast errors on asset growth, $T A G_{y}$ and debt growth, $D I_{y}$. Regression (i) shows that the scaled errors of forecasts made at the end of year $y$, after the debt is issued and the asset growth realized (but possibly before this has been revealed to investors) are negatively related to asset growth, $T A G_{y}$, and positively related to debt financing, $D I_{y}$ : analysts are less-over-optimistic about high growth firms, but are more optimistic about the firms that rely heavily on debt financing. Regression (ii) shows similar results for forecasts made at the end of year $y-1$, before the debt financing and asset growth are realized.

Thus, both the evidence on returns in the months following the debt financing, and the evidence on analyst forecast errors before and after the debt financing point strongly to an association between debt financing and over-valuation of the firm's stock. This is clearly inconsistent with market timing, but over-valuation and unrealistic investor expectations present a problem for managers whose performance will be assessed against this background of expectations, creating pressure on them to 'make the numbers'.

\section{Debt Issuance and Pressure on Managers}

We have argued that the 'making the numbers' motive will be strongest when managers are under strong pressure to perform because of poor past performance, their expectations of poor future performance, or simply because of over-optimistic investor expectations about future earnings that managers do not expect to be able to meet.

Table 9 reports equally weighted and value weighted characteristics of the firms in the 40 asset growth/debt issuance portfolios that affect the pressure on management to 'make the numbers'. Com- 
paring the high debt issuers in DI4 with the low debt issuers in DI1 we see in Panels A and B that for virtually every asset growth decile the high debt issuers have significantly lower returns on both assets and equity in year $y-1$ : this is consistent with cross section studies which typically find that the most profitable firms tend to borrow least. ${ }^{22}$

Panel $\mathrm{C}$ shows that the market-to-book $(M / B)$ ratio at the end of year $y-1$ is almost always lower for DI4 than for DI1. This is consistent with the finding of Fama and French (2012) that equity issuance is positively related to the price-to-book ratio but that the variation in the mix of new debt and equity in response to this variable is 'typically modest'. ${ }^{23}$ For $T A G$ decile 10 a shallow ' $U$-shaped' relation between $M / B$ and Debt Issuance quartile emerges. For the VW (EW) TAG10 portfolios the $M / B$ ratio for $D I 4$ is $4.03(3.04)$ as compared with an average ratio for the two middle debt issuance quartiles of around $3.7(2.7)$.

Panel D shows that firms that increase their debt the most in year $y$ already tend to have the highest debt ratios in year $y-1$ : in the three highest $T A G$ deciles the debt ratio for DI4 in year $y-1$ is around $30 \%$ as compared with less than $20 \%$ for $D I 1$, so that there is no evidence that heavy reliance on debt issuance to finance growth reflects simply the exploitation of unused debt capacity as firm debt ratios revert to the mean. However, we make no attempt to take account of different target debt ratios for different firms. Previous authors who do take account of different target debt ratios do find evidence of mean reversion using a regression approach but, as Fama and French (2012) point out, 'leverage targets are not generally a first order consideration in financing decisions', and in the regressions we shall report below we shall find evidence of mean reversion once we account for other factors. ${ }^{24}$ For positive growth firms, the debt ratio in year $y-1$ is a decreasing function of the TAG decile which is consistent with debt overhang theories of capital structure. ${ }^{25}$

Most importantly, as we saw in Table 7, the managers of the high debt issuers face the problem that at the end of year $y-1$ analysts are over-estimating their earnings per share for year $y+1$ by much more than they are over-estimating the earnings of the low debt issuers. For every $T A G$ decile the forecast errors are higher for DI4 than for DI1: on average by $5.3 \%$ (7.1\%) for the VW (EW) portfolios; this

\footnotetext{
${ }^{22}$ Rajan and Zingales (1995), Wald (1999), Booth, Aivazian, Demirguc-Kunt, and Maksimovic (2001).

${ }^{23}$ Myers (2002) reports that there is a 'strong inverse relation between the market-to-book ratio and debt ratios'. This may be because highly profitable firms often use their earnings to pay down debt.

${ }^{24}$ Only $19 \%$ of the firms in the Graham and Harvey (2001) survey said they did not have a target debt ratio or target range.

${ }^{25}$ Myers (1977).
} 
difference is a multiple of the scaled forecast for the DI1 firms. Thus, to the extent that managers are under pressure to 'make the numbers' expected by analysts, ${ }^{26}$ the managers of the firms that issue the most debt are under the most pressure.

Further evidence that the managers of firms in the high debt issuance quartile may be under pressure to perform is apparent in the average monthly abnormal returns for year $y-1$ shown in Panel E. Consistent with previous studies, we find that asset growth is positively associated with past returns. More significantly, for virtually every $T A G$ decile the abnormal returns on the high debt issuance quartile are below those of the low debt issuance quartile. For TAG10 the difference is 70 (80) basis points per month or $8.4 \%(9.6 \%)$ per year for the VW (EW) portfolios. This difference could also be interpreted in terms of the market timing hypothesis: firms tend to rely on equity issuance after their stock price has risen. ${ }^{27}$ But against this hypothesis is the lack of evidence in Table 4 of significant positive abnormal returns for the low debt issuance portfolios in months $[7,18]$ following the financing year. ${ }^{28}$ Overall, the univariate comparisons in Table 9 are consistent with the managers of high debt issuance firms being under greater pressure to perform because of poor past operating performance and negative stock returns as well as continuing excessive expectations about future performance. This is consistent with the predictions of the $M T N$ hypothesis

Table 10 casts further light on the pressure on managers. Newly appointed managers may be expected to be under strong pressure because of their lack of power relative to the board that appointed them. Panel A shows for each asset growth/debt issuance category the proportion of firms that appoint a new CEO in either year $y$ or year $y-1$. For all but the lowest $T A G$ decile the high debt issuers are more likely to have appointed a new CEO recently than the low debt issuers, and for most of the deciles they are more than twice as likely. To the extent that new CEO's are under pressure to prove themselves by 'making the numbers', this is further evidence in favor of the MTN hypothesis.

Panel $\mathrm{B}$ of the table provides evidence on the security of tenure of managers in the different asset

\footnotetext{
${ }^{26}$ That managers are under such pressure is suggested by the extensive literature on earnings management, and the tendency for reported earnings per share to cluster just above the consensus estimate (see for example Degeorge, Patel, and Zeckhauser (1999)). Graham, Harvey, and Rajgopal (2005) report that managers are willing to take costly real actions in order to achieve earnings targets based on analyst consensus estimates.

${ }^{27}$ See Hovakimian, Opler, and Titman (2001).

${ }^{28}$ During the announcement period, months $[1,6]$, firms in the low debt issuance quartile, DI1, have higher returns than firms in the high debt issuance quartile, $D I 4$, for virtually every $T A G$ decile. These results are not reported here.
} 
growth/debt issuance portfolios by showing the fraction of managers who are replaced in the three years following year $y$. Although the sample period is relatively short, it is clear that managers of the firms that issue the most debt have considerably less security of tenure: in eight of the asset growth deciles the proportion of managers who are replaced within 3 years is higher in DI4 than in DI1. Managers in the high debt issuance quartile do seem to be under more pressure to perform.

Table 11 reports the time series average of the cross-sectional standard deviation of the change in the Return on Assets from year $y$ to year $y+1$ within each debt issuance quartile for each $T A G$ decile. If this variable captures asset risk and if debt issuance is negatively associated with asset risk, then we should expect that for each asset growth category the standard deviation would decrease monotonically as we move from $D I 1$ to $D I 4$. In fact we find for almost all $T A G$ deciles a U-shaped relation between this measure of asset risk and debt issuance: the asset risk of both the low debt issuance category, DI1, and of the high debt issuance DI4, is higher than that of the intermediate debt issuance categories, $D I 2, D I 3$. This $U$-shaped relation is inconsistent with low risk firms choosing higher leverage, but it is consistent either with a scenario in which managers who face a more uncertain future choose a high debt financing ratio in the hope that leverage will offset low returns on assets, or with a scenario in which managers who are faced with poor investment prospects 'roll the dice' both by making risky investments and by financing those investments with leverage. Some suggestion that managers of high debt issuance firms may indeed be 'rolling the dice' is contained in the evidence we saw in Panel B of Table 10 which shows that the CEO's of DI4 are more likely to be replaced in the three years following year $y$ than are the CEO's of DI1 firms.

Table 12 reports the results of panel regressions using individual firm data to predict $D I_{y}$, the growth in debt as a proportion of assets. In the regressions that include the relative earnings yield variable, $(E / P) / B a a$, we include only firm-years for which the lagged earnings are positive. We include as regressors variables that capture the current debt ratio, the asset growth to be financed, profitability, and current and lagged stock returns. We also include variables that capture the pressure on management to 'make the numbers', as well as the ratio of the earnings-yield to the Baa yield to capture variation in the ability of managers to 'improve the numbers' by debt financing. Regression (i) includes only the first set of variables and explains $59 \%$ of the variation in normalized debt growth. The lagged debt ratio, $(D / A)_{y-1}$, is strongly and significantly negatively associated with debt issuance in all of the regressions, implying an element of global mean reversion in debt ratios. The product of the lagged debt ratio and the asset growth rate, $(D / A)_{y-1} T A G_{y}$, is the debt growth that would arise from 
asset growth if the debt to asset ratio remained constant; the positive and significant coefficient on this variable in all of the regressions implies a degree of inertia in debt ratios. However, the positive and highly significant coefficient on $T A G_{y}$ implies that higher asset growth implies proportionately higher reliance on debt financing which is consistent with the Myers (1984) pecking order story. The negative and significant coefficient on $R O A_{y}$ implies that ceteris paribus roughly $20 \%$ of the pre-tax return on assets is available to finance asset growth. The change in Return on Assets from year $y-1$ to year $y, \Delta R O A_{y}$, is negatively associated with the amount of debt financing in the regressions that include the ratio of the earnings yield to the bond yield as an independent variable. Since we have already accounted for the effect of current profitability, $R O A_{y}$, the influence of this variable cannot be through the financing channel: we shall discuss it further below. Stock returns in the current and previous year, $\operatorname{Ret}_{y}$ and $\operatorname{Ret}_{y-1}$, are significantly negatively associated with debt issuance. However, the effect is quantitatively modest: a $50 \%$ stock return spread over these two years would decrease debt financing by only around $0.5 \%$ of assets in year $y$.

Operating risk, as measured by the standard deviation of the change in Return on Assets between years $y$ and $y+1$ for all firms within the same asset growth/debt growth portfolio, $S D R O A_{y+1}$, has a highly significant negative effect on debt issuance. This is consistent with bankruptcy cost and costly financial distress considerations, as well as with risk aversion on the part of managers.

Our most significant findings relate to the variables that capture pressure on management to 'make the numbers', and their ability to do so by issuing debt. First, as we have noted, deteriorating operating performance as captured by the change in Return on Assets from the previous year, $\triangle R O A_{y}$, is negatively and significantly associated with debt financing. Moreover, debt issuance is strongly negatively related to the future change in Return on Assets, $\triangle R O A_{y+1}$ also as predicted by $M T N 1$. This can only be because management, in making its financing decision in year $y$, takes into account its knowledge of changes in profitability in the current and following year.

Regressions (v)-(vii) show that the greater is the firm's under-performance relative to expectations in year $y$, as measured by the scaled earnings forecast error for year $y, F E(y-1, y)$, the more inclined management is to rely on debt; note that this is after taking account of the stock return in year $y$, and the change in profitability, $\triangle R O A_{y}$. This is consistent with MTN6: managers of firms that are under-performing relative to analyst expectations are more likely to feel pressure to 'make the numbers' and relying on debt financing is one way to accomplish this.

As previously noted, debt financing will only lead to an increase in earnings per share if the earnings 
yield is above the cost of debt. We include the lagged ratio of the earnings yield to the cost of debt as measured by the average of the weekly yields during the year on Moody's Seasoned Baa Corporate Bond Yield Index, $((E / P) / B a a)_{y-1}$, in regressions (ii), (iv), (vii) and (viii) to capture this effect. Consistent with MTN5 and the facilitating effect of a high earnings yield for debt financing to be efficacious in making the numbers, the coefficient is positive and significant, except in regression (iv) and regression (viii) which has only a small number of observations. In regressions (i) and (ii) the coefficient of the lagged market to book ratio, $(M / B)_{y-1}$ is negative and highly significant. However, it becomes insignificant in regressions that include the relative earnings yield variable. This variable does not capture market timing since, as we have seen, debt issuance is not consistent with the market timing motive. It seems that the effect of the market to book ratio arises because of its association with earnings (and book value) dilution from stock issuance. Finally, in regression (viii) the coefficient of the dummy variable that captures new CEO appointments is positive but not significant, while $S E N S I_{y}$, the relative sensitivity of CEO compensation to the stock price, is marginally significantly negatively associated with debt financing: this is consistent with Frank and Goyal (2007) who find that managerial pay for performance sensitivity is negatively associated with leverage ratios. We note that data requirements substantially reduce the number of observations for this regression.

The EPO hypothesis implies that the negative relation between debt financing and future changes in profitability is due to the precautionary demand for external finance which creates a negative relation between external finance, $(D I+S I)_{y}$, and the future change in profitability, $\Delta R O A_{y+1}$, and the pecking order hypothesis which posits a positive relation between external financing and debt financing. We have already seen in Table 1 that the relation between external finance and the future change in profitability is positive, not negative. Regressions (ii), (iv) and (vi) replace the asset growth variable, $T A G_{y}$, by the external financing variable, $(D I+S I)_{y}$. Consistent with the pecking order hypothesis, the coefficient of this variable is positive and highly significant: more external finance implies more debt finance. However, contrary to EPO2, the prediction of the EPO hypothesis that the amount of debt financing will not be influenced by anticipations of future profitability once account is taken of the amount of external finance, we see that the coefficient of $\Delta R O A_{y+1}$ remains negative and highly significant.

Finally, to ensure that the results are not driven by sample selection bias ${ }^{29}$ due to including only firms that issue positive amounts of debt, the regressions were repeated for all firms and then for all

\footnotetext{
${ }^{29}$ See Heckman (1979).
} 
firms for which $T A G>0$. The findings are even stronger in these larger samples. Thus the results in Table 12 provide no support for the extended pecking order hypothesis, and confirm our earlier findings of an association between debt financing and a subsequent decline in profitability as measured by the Return on Assets. Moreover, the results are consistent with predictions MTN5 and MTN6: a high earnings yield relative to the bond rate increases reliance on debt financing, and pressure on management related to unmet analyst expectations also increases debt financing.

\section{Conclusion}

In this paper we have provided new evidence on the determinants of firm financing choices. We have shown first that, for given levels of total asset growth or total external financing, increased reliance on debt financing predicts worse operating profitability in the following year. This implies that at the time the managers are making their financing decisions, they have information about the future change in operating profitability and that they react to declining future profitability by increasing leverage. This is contrary to the predictions of a static tax shield and bankruptcy cost model of capital structure which would predict a reduced reliance on debt financing under these circumstances. We have considered three hypotheses to account for this apparently perverse reaction to bad news about future profitability.

The market timing hypothesis predicts that heavy debt issuance will be associated with underpricing of the stock which implies high risk adjusted future stock returns and over-pessimistic analyst earnings forecasts. We reject both of these implications.

The extended pecking order hypothesis implies that a heavy reliance on external financing will predict future declines in profitability, and that the relation between debt financing and future changes in profitability will disappear once account is taken of the quantity of external finance. We find that total external financing is associated with an increase in future profitability when the amount of debt financing is taken into account, and the relation between debt financing and future declines in profitability is maintained when total external financing is taken into account so that both predictions of the EPO hypothesis are rejected.

While these two hypotheses are rejected we find in support of the making the numbers hypothesis that not only does a heavy reliance on debt financing tend to forecast a decline in Return on Assets, so that managers tend to rely more heavily on debt finance when they anticipate a decline in profitability, 
but that debt issuance tends to raise the Return on Equity for a given Return on Assets which helps managers to 'make the numbers' in an environment of declining profitability. Moreover the managers of the firms that rely more heavily on debt to finance their asset growth are under more pressure to perform in that their stock is more overpriced, past and current stock returns are lower, operating profitability has declined more and analysts are more over-optimistic about current and future earnings. Finally, when the earnings yield is higher relative to the bond rate so that the earnings per share enhancement effect of debt financing is higher, managers rely more heavily on debt. While this evidence is only circumstantial, the survey evidence of Graham, Harvey, and Rajgopal (2005) that 'earnings, not cash flows, are the key metric considered by outsiders' and the extensive accounting literature that documents the manipulation of corporate earnings both through accruals and changes to real activities lend further plausibility to the case that corporate financing decisions are influenced by a desire to meet the numbers at times of stress.

We also find that ceteris paribus debt financing is decreasing in a measure of asset risk and in a measure of the sensitivity of the CEO's wealth to the stock price. This is consistent with managerial risk aversion also playing a role in financing decisions. ${ }^{30}$ However, we also find that firms in the highest quartile of debt issuers actually have higher risk as measured by our proxy than firms in the middle quartiles of debt issuance. We interpret this as evidence of managers in serious straits 'swinging for the fence', and we find evidence that CEO's of firms in this highest quartile of debt issuers are more likely to be replaced in the next three years.

The combination of deteriorating fundamentals, over-optimistic analysts and negative future stock returns for firms that rely heavily on debt finance suggests that the market is slow to comprehend the prospects of these firms despite the cue implicit in the debt financing, and that when it does catch up to the change in $R O A$ and $R O E$ the stock price undergoes a negative adjustment.

More generally, we have provided new evidence that managerial concerns are of importance in financing decisions. As the remarks of Myers quoted in the introduction suggest, these concerns will differ according to the condition of the firm and the manager and the terms and security of employment.

\footnotetext{
${ }^{30}$ Graham and Narasimhan (2004) and Malmendier, Tate, and Yan (2011) have demonstrated the importance of individual managerial traits for corporate financing decisions.
} 


\section{References}

Ackermann, J., 2010, The new architecture of financial regulation: Will it prevent another crisis?, Special Paper 194, LSE Financial Markets Group.

Baber, W.R., P.M. Fairfield, and J.A. Haggard, 1991, The effect of concern about reported income on discretionary spending decisions: the case of research and development, Accounting Review 66, $818-829$.

Baker, M., R.S. Ruback, and J. Wurgler, 2007, Behavioral corporate finance: a survey, in Eckbo, B.E. (Ed.), Handbook of Corporate Finance, Vol 1. North Holland/Elsevier Handbooks in Finance.

Baker, M., and J. Wurgler, 2000, The equity share in new issues and aggregate stock returns, Journal of Finance 55, 2219-2257.

Baker, M., and J. Wurgler, 2002, Market timing and capital structure, Journal of Finance 57, 1-32.

Baxter, N.D., and J.G. Cragg, 1970, Corporate choice among long term financing instruments, Review of Economics and Statistics 52, 225-235.

Berger, P.G., E. Ofek, and D.L. Yermack, 1997, Managerial Entrenchment and Capital Structure Decision, Journal of Finance 52, 1411-1438.

Berk, J. B., R. C. Green, and V. Naik, 1999, Optimal investment, growth options, and security returns, Journal of Finance 54, 1553-1607.

Birkeland, M.K., A.E. Eriksen, and E. Ueland, 2011, Executive incentives and capital structure, Working Paper, University of Trondheim.

Booth, L., V. Aivazian, A. Demirguc-Kunt, and V. Maksimovic, 2001, Capital structures in developing countries, Journal of Finance 56, 87-130.

Bradshaw, M.T., S.A. Richardson, and R.G. Sloan, 2006, The relation between corporate financing activities, analysts forecasts and stock return, Journal of Accounting and Economics 42, 53-85.

Brennan, M.J., and E.S. Schwartz, 1984, Optimal financial policy and firm valuation, Journal of Finance 39, 593-607. 
Bruns, W., and K. Merchant, 1990, The dangerous morality of managing earnings, Management Accounting 7, 22-25.

Bushee, B., 1998, The influence of institutional investors on myopic R\&D investment behavior, Accounting Review 73, 305-333.

Carlson, M., A. Fisher, and R. Giammarino, 2004, Corporate investment and asset price dynamics: Implications for the cross-section of returns, Journal of Finance 59, 2577-2603.

Chen, N.-F., R. Roll, and S. Ross, 1986, Economic forces and the stock market, Journal of Business $59,383-403$.

Christie, A., 1987, On cross-sectional analysis in accounting research, Journal of Accounting and Economics 9, 231-258.

Cooper, I., and R. Priestley, 2011, Real investment and risk dynamics, Journal of Financial Economics $101,182-205$.

Cooper, M.J., H. Gulen, and M.J. Schill, 2008, Asset growth and the cross-section of stock returns, Journal of Finance 63, 1609-1651.

Daniel, K., and S. Titman, 2006, Market reactions to tangible and intangible information, Journal of Finance 61, 1605-1643.

DeAngelo, H., L. DeAngelo, and R.M. Stulz, 2010, Seasoned equity offerings, market timing and the corporate life cycle, Journal of Financial Economics 95, 275-295.

DeAngelo, H., L. DeAngelo, and T. Whited, 2011, Capital structure dynamics and transitory debt, Journal of Financial Economics 99, 235-261.

DeAngelo, H., and R. Roll, 2015, How stable are corporate capital structures, Journal of Finance 70, $373-418$.

Deechow, P.M., and R. Sloan, 1991, Executive incentives and the horizon problem: an empirical investigation, Journal of Accounting and Economics 14, 51-89.

Degeorge, F., J. Patel, and R. Zeckhauser, 1999, Earnings management to exceed thresholds, Journal of Business 72, 1-33. 
Driscoll, J. C., and A. C. Kraay, 1998, Consistent covariance matrix estimation with spatially dependent panel data, Review of Economics and Statistics 80, 549-560.

Fama, E.F., and K.R. French, 1992, The cross-section of expected stock returns, Journal of Finance $47,427-465$.

Fama, E.F., and K.R. French, 2008, Dissecting Anomalies, Journal of Finance 63, 1653-1678.

Fama, E.F., and K.R. French, 2012, Capital structure choices, Critical Finance Review 1, 59-101.

Firth, M., 1995, The impact of institutional stockholders and managerial interests on the capital structure of firms, Managerial and Decision Economics 16, 167-175.

Flannery, M., and K. Rangan, 2006, Partial adjustment towards target capital structures, Journal of Financial Economics 79, 469-506.

Frank, M.Z., and V.K. Goyal, 2007, Corporate leverage: How much do managers really matter?, Working Paper, Hong Kong University of Science and Technology.

Frank, M.Z., and V.K. Goyal, 2009, Capital Structure Decisions: Which Factors Are Reliably Important?, Financial Management 38, 1-37.

Friend, I., and L.H.P. Lang, 1988, An empirical test of the impact of managerial self-interest on corporate capital structure, Journal of Financial Economics 79, 469-506.

Gamba, A., and A. Triantis, 2008, The value of financial flexibility, Journal of Finance 63, 2263-2296.

Graham, J.R., and C.R. Harvey, 2001, The theory and practice of corporate finance: evidence from the field, Journal of Financial Economics 60, 187-243.

Graham, J.R., C.R. Harvey, and S. Rajgopal, 2005, The economic implications of corporate financial reporting, Journal of Accounting and Economics 40, 3-73.

Graham, J.R., and K. Narasimhan, 2004, Corporate survival and managerial experiences during the Great Depression, Working Paper, Duke University.

Heckman, J., 1979, Sample selection bias as a specification error, Econometrica 47, 153-161.

Hennessy, C.A., and T.M. Whited, 2005, Debt dynamics, Journal of Finance 60, 1129-1165. 
Hovakimian, A, T. Opler, and S. Titman, 2001, The debt-equity choice, Journal of Financial and Quantitative Analysis 36, 1-24.

Jung, K., Y.-C. Kim, and R. Stulz, 1996, Timing, investment opportunities, managerial discretion and the security issue decision, Journal of Financial Ecnomics 42, 159-185.

Lambrecht, B., and S.C. Myers, 2008, Debt and managerial rents in a real-options model of the firm, Journal of Financial Ecnomics 89, 209-231.

Leary, M.T., and M.R. Roberts, 2010, The pecking order, debt capacity, and information asymmetry, Journal of Financial Economics 95, 332-355.

Lemmon, M.L., M.R. Roberts, and J.F. Zender, 2008, Back to the beginning: persistence and the cross-section of corporate capital structure, Journal of Finance 63, 1575-1608.

Liu, Y., Y. Ning, and W.N. Davidson, 2010, Earnings management surrounding new debt issues, Financial Review 45, 659-681.

Malmendier, U., G. Tate, and J. Yan, 2011, Overconfidence and early-life experiences: the effect of managerial traits on corporate financial policies, Journal of Finance 66, 1687-1733.

Marsh, P., 1982, The choice between equity and debt, Journal of Finance 37, 121-144.

Matsunaga, S., and C. Park, 2001, The effect of missing a quarterly earnings benchmark on the CEO's annual bonus, Accounting Review 76, 313-332.

Mehran, H., 1992, Executive incentive plans, corporate control, and capital structure, Journal of Financial and Quantitative Analysis 27, 539-560.

Morellec, E., 2004, Can managerial discretion explain observed leverage ratios?, Review of Financial Studies 17, 257-294.

Myers, S.C., 1977, Determinants of corporate borrowing, Journal of Financial Economics 5, 147-176.

Myers, S.C., 1984, The capital structure puzzle, Journal of Finance 39, 575-592.

Myers, S.C., 2002, Financing of corporations, in Constantinides, G.M., M. Harris, and R. Stulz, (Eds.), Handbook of the Economics of Finance. North Holland/Elsevier Handbooks in Finance. 
Rajan, R., and L. Zingales, 1995, What do we know about capital structure? Some evidence from international data, Journal of Finance 50, 1421-1460.

Stulz, R.M., 1990, Managerial discretion and optimal financing policies, Journal of Financial Economics 26, 3-27.

Titman, S., J. Wei, and F. Xie, 2004, Capital investments and stock returns, Journal of Financial and Quantitative Analysis 39, 677-700.

Titman, S., and R. Wessels, 1988, The determinants of capital structure choice, Journal of Finance $42,1-19$.

Wald, J., 1999, How firm characteristics affect capital structure: an international comparison, Journal of Financial Research 22, 161-187.

Welch, I., 2004, Capital structure and stock returns, Journal of Political Economy 112, 106-130.

Welch, I., 2011, Two common problems in capital structure research: the financial-debt-to-asset ratio and issuing activity versus leverage changes, International Review of Finance 11, 1-17.

Zwiebel, J., 1996, Dynamic capital structure policy under managerial entrenchment, American Economic Review 86, 1197-1215. 


\begin{tabular}{lrrrr}
\hline & (i) & (ii) & (iii) & (iv) \\
Dependent Variable & $\Delta \mathrm{ROA}_{y+1}$ & $\Delta \mathrm{ROA}_{y+1}$ & $\Delta \mathrm{ROE}_{y+1}$ & $\Delta \mathrm{ROE}_{y+1}$ \\
\hline $\mathrm{TAG}_{y}$ & $0.026^{* * *}$ & & $0.016^{*}$ & \\
& $(4.13)$ & & $(2.63)$ & \\
$(\mathrm{DI}+\mathrm{SI})_{y}$ & & $0.014^{*}$ & & 0.004 \\
& & $(2.57)$ & & $(0.47)$ \\
$\mathrm{DI}_{y}$ & $-0.079^{* * *}$ & $-0.054^{* * *}$ & $-0.036^{*}$ & -0.016 \\
& $(-7.82)$ & $(-5.41)$ & $(-2.34)$ & $(-0.97)$ \\
$\mathrm{ROA}_{y}$ & $-0.534^{* * *}$ & $-0.517^{* * *}$ & & \\
& $(-42.79)$ & $(-45.93)$ & & \\
$\mathrm{ROE}_{y}$ & & & $-0.639^{* * *}$ & $-0.642^{* * *}$ \\
& & & $(-28.63)$ & $(-25.24)$ \\
$\mathrm{Constant}$ & 0.006 & $0.029^{* * *}$ & $0.037^{* * *}$ & 0.052 \\
$R^{2}$ & $(0.80)$ & $(11.92)$ & $(4.92)$ & $(14.04)$ \\
Obs. & 0.292 & 0.286 & 0.285 & 0.289 \\
& 39316 & 34962 & 34186 & 30286 \\
\hline
\end{tabular}

Table 1: Regressions of Changes in Return on Assets and Return on Equity on Total Asset Growth and Debt Issuance. The table reports the results of panel regressions of changes in Return on Assets and Return on Equity from year $y$ to year $y+1$ on lagged values of the variables, asset growth, $T A G_{y}$, debt issuance, $D I_{y}$, and external finance, $(D I+S I)_{y}$. Firms are included in the regression only if their debt issuance is positive in year $y$. $R O E_{y}$ is set to missing if the share price is below one dollar. All variables are winsorized at the $1 \%$ level. The sample period is 1968-2010. The regressions include firm fixed effects. $t$-statistics which are reported in brackets are based on Driscoll and Kraay (1998) standard errors. Asterisks correspond to the following $p$-values: $* p<0.05, * * p<0.01, * * * p<0.001$. 


\begin{tabular}{|c|c|c|c|c|c|c|}
\hline & (i) & (ii) & (iii) & (iv) & $(\mathrm{v})$ & (vi) \\
\hline Dependent Variable & $\Delta \mathrm{ROE}_{y+1}$ & $\Delta \mathrm{ROE}_{y+1}$ & $\Delta \mathrm{ROE}_{y+1}$ & $\Delta \mathrm{ROE}_{y+1}$ & $\Delta \mathrm{ROE}_{y+1}$ & $\Delta \mathrm{ROE}_{y+1}$ \\
\hline$\Delta \mathrm{ROA}_{y+1}$ & $\begin{array}{r}1.393^{* * *} \\
(52.75)\end{array}$ & $\begin{array}{r}1.387^{* * *} \\
(52.90)\end{array}$ & $\begin{array}{r}1.383^{* * *} \\
(50.56)\end{array}$ & & $\begin{array}{r}0.641^{* * *} \\
(11.28)\end{array}$ & \\
\hline $\mathrm{DI}_{y}$ & $\begin{array}{r}0.095^{* * *} \\
(8.89)\end{array}$ & $\begin{array}{r}0.084^{* * *} \\
(7.40)\end{array}$ & $\begin{array}{r}0.101^{* * *} \\
(4.92)\end{array}$ & $\begin{array}{r}0.161^{* * * *} \\
(8.55)\end{array}$ & $\begin{array}{r}0.143^{* * *} \\
(7.13)\end{array}$ & \\
\hline$(\mathrm{D} / \mathrm{A})_{y}$ & & $\begin{array}{r}0.043^{*} \\
(2.53)\end{array}$ & $\begin{array}{r}0.036^{*} \\
(2.58)\end{array}$ & & & $\begin{array}{r}0.037^{*} \\
(2.68)\end{array}$ \\
\hline $\mathrm{TAG}_{y}$ & & & $\begin{array}{l}-0.010 \\
(-0.86)\end{array}$ & $\begin{array}{l}-0.020 \\
(-1.71)\end{array}$ & $\begin{array}{l}-0.011 \\
(-0.91)\end{array}$ & $\begin{array}{l}-0.013 \\
(-1.13)\end{array}$ \\
\hline$(\mathrm{A} / \mathrm{EQ})_{y} \times \Delta \mathrm{ROA}_{y+1}$ & & & & $\begin{array}{r}0.522^{* * *} \\
(46.36)\end{array}$ & $\begin{array}{r}0.314^{* * *} \\
(15.83)\end{array}$ & \\
\hline$\Delta \mathrm{ROA}_{y+1}^{+}$ & & & & & & $\begin{array}{r}1.482^{* * *} \\
(32.96)\end{array}$ \\
\hline$\Delta \mathrm{ROA}_{y+1}^{-}$ & & & & & & $\begin{array}{r}1.323^{* * *} \\
(40.05)\end{array}$ \\
\hline $\mathrm{DI}_{y} \mid \Delta \mathrm{ROA}_{y+1}>0$ & & & & & & $\begin{array}{r}0.086^{* *} \\
(3.46)\end{array}$ \\
\hline $\mathrm{DI}_{y} \mid \Delta \mathrm{ROA}_{y+1}<0$ & & & & & & $\begin{array}{r}0.107^{* * *} \\
(4.96)\end{array}$ \\
\hline Constant & $\begin{array}{r}-0.010^{* * *} \\
(-6.09)\end{array}$ & $\begin{array}{r}-0.022^{* * *} \\
(-4.39)\end{array}$ & $\begin{array}{r}-0.019 * * * \\
(-4.56)\end{array}$ & $\begin{array}{r}-0.015^{* * *} \\
(-7.62)\end{array}$ & $\begin{array}{r}-0.013^{* * *} \\
(-7.04)\end{array}$ & $\begin{array}{r}-0.022^{* * *} \\
(-5.70)\end{array}$ \\
\hline$R^{2}$ & 0.367 & 0.368 & 0.368 & 0.381 & 0.398 & 0.368 \\
\hline Obs. & 34185 & 34185 & 34185 & 34185 & 34185 & 34185 \\
\hline
\end{tabular}

Table 2: Regressions of Change in Return on Equity on Change in Return on Assets and Debt Issuance. The table reports the results of panel regressions of the change in the Return on Equity from year $y$ to year $y+1, \Delta R O E_{y+1}$, on the contemporaneous change in the Return on Assets, $\triangle R O A_{y+1}$, debt issuance in year $y, D I_{y}$, debt ratio at the end of year $y,(D / A)_{y}$, and Total Asset Growth in year $y, T A G_{y}$. Firms are included in the regression only if their debt issue is positive in year $y .(A / E Q)_{y}$ is the ratio of total assets to equity at the end of year $y . \Delta R O A_{y+1}^{+}\left(\Delta R O A_{y+1}^{-}\right)$is the change in the Return on Assets if it is positive (negative) and zero otherwise. $D I_{y} \mid \Delta R O A_{y+1}>0$ $\left(D I_{y} \mid \Delta R O A_{y+1}<0\right)$ is the amount of debt issuance in year $y$ if the change in Return on Assets from year $y$ to year $y+1$ is positive (negative) and zero otherwise. All variables are winsorized at the $1 \%$ level. The sample period is 1968-2010. The regressions include firm fixed effects. $t$-statistics which are reported in brackets are based on Driscoll and Kraay (1998) standard errors. Asterisks correspond to the following $p$-values: $* p<0.05, * * p<0.01, * * * p<0.001$. 


\begin{tabular}{|c|c|c|c|c|}
\hline $\begin{array}{l}\text { Debt Issuance: } \\
\text { Asset Growth }\end{array}$ & $D I 1$ & $\overline{D I 2}$ & DI3 & $D I 4$ \\
\hline \multicolumn{5}{|c|}{ Panel A. Average Total Asset Growth } \\
\hline Low & -0.301 & -0.299 & -0.299 & -0.331 \\
\hline 2 & -0.100 & -0.097 & -0.100 & -0.102 \\
\hline 3 & -0.024 & -0.025 & -0.025 & -0.026 \\
\hline 4 & 0.020 & 0.020 & 0.020 & 0.020 \\
\hline 5 & 0.052 & 0.052 & 0.053 & 0.052 \\
\hline 6 & 0.084 & 0.085 & 0.086 & 0.087 \\
\hline 7 & 0.126 & 0.125 & 0.129 & 0.129 \\
\hline 8 & 0.186 & 0.186 & 0.190 & 0.195 \\
\hline 9 & 0.305 & 0.303 & 0.314 & 0.343 \\
\hline High & 0.859 & 0.745 & 0.884 & 3.031 \\
\hline \multicolumn{5}{|c|}{ Panel B. Average Total Debt Issuance } \\
\hline Low & 0.007 & 0.025 & 0.062 & 0.225 \\
\hline 2 & 0.006 & 0.022 & 0.051 & 0.195 \\
\hline 3 & 0.005 & 0.017 & 0.039 & 0.143 \\
\hline 4 & 0.005 & 0.018 & 0.039 & 0.107 \\
\hline 5 & 0.006 & 0.021 & 0.042 & 0.115 \\
\hline 6 & 0.008 & 0.027 & 0.051 & 0.115 \\
\hline 7 & 0.013 & 0.041 & 0.070 & 0.144 \\
\hline 8 & 0.019 & 0.060 & 0.102 & 0.192 \\
\hline 9 & 0.032 & 0.102 & 0.170 & 0.296 \\
\hline High & 0.077 & 0.254 & 0.445 & 1.518 \\
\hline \multicolumn{5}{|c|}{ Panel C. Average Total Equity Growth } \\
\hline Low & -0.265 & -0.270 & -0.314 & -0.499 \\
\hline 2 & -0.085 & -0.104 & -0.118 & -0.265 \\
\hline 3 & -0.022 & -0.032 & -0.053 & -0.148 \\
\hline 4 & 0.009 & -0.001 & -0.016 & -0.081 \\
\hline 5 & 0.026 & 0.019 & 0.004 & -0.060 \\
\hline 6 & 0.043 & 0.033 & 0.020 & -0.029 \\
\hline 7 & 0.067 & 0.048 & 0.030 & -0.025 \\
\hline 8 & 0.097 & 0.068 & 0.048 & -0.016 \\
\hline 9 & 0.169 & 0.114 & 0.076 & 0.004 \\
\hline High & 0.568 & 0.303 & 0.267 & 0.833 \\
\hline
\end{tabular}




\begin{tabular}{|c|c|c|c|c|}
\hline $\begin{array}{l}\text { Debt Issuance: } \\
\text { Asset Growth }\end{array}$ & $D I 1$ & $D I 2$ & $D I 3$ & DI4 \\
\hline \multicolumn{5}{|c|}{ Panel D. Average Firm Value } \\
\hline Low & 626 & 758 & 657 & 365 \\
\hline 2 & 3744 & 1763 & 1044 & 986 \\
\hline 3 & 4181 & 3600 & 2096 & 1925 \\
\hline 4 & 5493 & 6308 & 4931 & 3691 \\
\hline 5 & 9187 & 6992 & 7195 & 3499 \\
\hline 6 & 9186 & 7530 & 6343 & 4251 \\
\hline 7 & 6741 & 8573 & 7523 & 5459 \\
\hline 8 & 6426 & 5604 & 5879 & 2999 \\
\hline 9 & 5499 & 5363 & 5264 & 2484 \\
\hline High & 3176 & 3881 & 3742 & 2466 \\
\hline \multicolumn{5}{|c|}{ Panel E. Average Total Equity Value } \\
\hline Low & 116 & -119 & 31 & 22 \\
\hline 2 & 824 & 420 & 212 & 80 \\
\hline 3 & 1179 & 1008 & 508 & 332 \\
\hline 4 & 1433 & 1764 & 1202 & 536 \\
\hline 5 & 2457 & 1821 & 1700 & 735 \\
\hline 6 & 2289 & 1894 & 1428 & 1072 \\
\hline 7 & 1908 & 2140 & 1510 & 950 \\
\hline 8 & 1773 & 1372 & 1332 & 584 \\
\hline 9 & 1406 & 1434 & 1058 & 509 \\
\hline High & 848 & 1061 & 865 & 532 \\
\hline \multicolumn{5}{|c|}{ Panel F. Average Number of Firms } \\
\hline Low & 11 & 11 & 11 & 10 \\
\hline 2 & 13 & 13 & 13 & 13 \\
\hline 3 & 15 & 15 & 15 & 15 \\
\hline 4 & 20 & 19 & 19 & 19 \\
\hline 5 & 25 & 24 & 25 & 24 \\
\hline 6 & 28 & 28 & 28 & 28 \\
\hline 7 & 32 & 32 & 32 & 31 \\
\hline 8 & 35 & 34 & 35 & 34 \\
\hline 9 & 37 & 36 & 37 & 36 \\
\hline High & 39 & 39 & 39 & 39 \\
\hline
\end{tabular}

Table 3: Average Annual Firm Characteristics for Portfolios Formed on Total Asset Growth and Debt Issuance. The table reports summary statistics based on equally weighted firm characteristics for the 40 asset growth/debt issuance portfolios. Each year 10 portfolios are formed by sorting firms on their Total Asset Growth during the year. Firms with positive debt issuance within each asset growth portfolio are then assigned to one of 4 sub-portfolios based on the change in the Total Debt during the year expressed as a proportion of the beginning of year total assets. Firms in sub-portfolios DI4 increase their debt the most and firms in DI4 increase their debt the least. The sample period is from 1968 to 2010. 


\begin{tabular}{|c|c|c|c|c|c|}
\hline $\begin{array}{l}\text { Debt Issuance: } \\
\text { Asset Growth }\end{array}$ & $D I 1$ & $D I 2$ & $D I 3$ & $D I 4$ & $D I 4-D I 1$ \\
\hline & \multicolumn{5}{|c|}{ Panel A. Value Weighted } \\
\hline Low & $\begin{array}{l}0.003 \\
(0.62)\end{array}$ & $\begin{array}{l}0.002 \\
(0.57)\end{array}$ & $\begin{array}{l}-0.003 \\
(-0.54)\end{array}$ & $\begin{array}{l}-0.003 \\
(-0.53)\end{array}$ & -0.006 \\
\hline 2 & $\begin{array}{l}0.001 \\
(0.28)\end{array}$ & $\begin{array}{l}-0.002 \\
(-0.66)\end{array}$ & $\begin{array}{l}-0.000 \\
(-0.01)\end{array}$ & $\begin{array}{l}-0.006 \\
(-1.70)\end{array}$ & -0.007 \\
\hline 3 & $\begin{array}{l}-0.001 \\
(1.64)\end{array}$ & $\begin{array}{l}-0.003 \\
(-0.46)\end{array}$ & $\begin{array}{l}0.005 \\
(-1.34)\end{array}$ & $\begin{array}{l}0.002 \\
(1.87)\end{array}$ & 0.003 \\
\hline 4 & $\begin{array}{l}0.002 \\
(0.99)\end{array}$ & $\begin{array}{l}0.004^{*} \\
(2.00)\end{array}$ & $\begin{array}{l}0.001 \\
(0.45)\end{array}$ & $\begin{array}{l}-0.001 \\
(-0.46)\end{array}$ & -0.003 \\
\hline 5 & $\begin{array}{l}0.002 \\
(1.07)\end{array}$ & $\begin{array}{l}0.001 \\
(0.88)\end{array}$ & $\begin{array}{l}0.001 \\
(0.46)\end{array}$ & $\begin{array}{l}0.002 \\
(0.89)\end{array}$ & 0.000 \\
\hline 6 & $\begin{array}{l}0.002 \\
(1.11)\end{array}$ & $\begin{array}{l}-0.000 \\
(-0.01)\end{array}$ & $\begin{array}{l}-0.000 \\
(-0.35)\end{array}$ & $\begin{array}{l}0.001 \\
(0.65)\end{array}$ & -0.001 \\
\hline 7 & $\begin{array}{l}0.002 \\
(1.34)\end{array}$ & $\begin{array}{l}0.001 \\
(0.66)\end{array}$ & $\begin{array}{l}0.003^{*} \\
(2.36)\end{array}$ & $\begin{array}{c}-0.003^{*} \\
(-2.01)\end{array}$ & -0.005 \\
\hline 8 & $\begin{array}{l}0.000 \\
(0.14)\end{array}$ & $\begin{array}{l}0.000 \\
(0.21)\end{array}$ & $\begin{array}{l}-0.000 \\
(-0.36)\end{array}$ & $\begin{array}{l}-0.001 \\
(-0.45)\end{array}$ & -0.001 \\
\hline 9 & $\begin{array}{l}0.003 \\
(1.91)\end{array}$ & $\begin{array}{l}0.001 \\
(0.83)\end{array}$ & $\begin{array}{c}-0.005^{* * *} \\
(-3.41)\end{array}$ & $\begin{array}{l}-0.001 \\
(-0.33)\end{array}$ & -0.004 \\
\hline High & $\begin{array}{l}-0.003 \\
(-1.52)\end{array}$ & $\begin{array}{c}-0.004^{*} \\
(-2.14)\end{array}$ & $\begin{array}{c}-0.005^{* *} \\
(-3.05)\end{array}$ & $\begin{array}{c}-0.009^{* * *} \\
(-4.11)\end{array}$ & -0.006 \\
\hline \multirow[t]{2}{*}{ High-Low } & -0.006 & -0.006 & -0.002 & -0.006 & \\
\hline & \multicolumn{5}{|c|}{ Panel B. Equal Weighted } \\
\hline Low & $\begin{array}{l}0.006 \\
(1.09)\end{array}$ & $\begin{array}{l}0.000 \\
(0.00)\end{array}$ & $\begin{array}{l}-0.006 \\
(-1.34)\end{array}$ & $\begin{array}{l}-0.002 \\
(-0.43)\end{array}$ & -0.008 \\
\hline 2 & $\begin{array}{l}0.002 \\
(0.73)\end{array}$ & $\begin{array}{l}0.005 \\
(1.41)\end{array}$ & $\begin{array}{l}-0.000 \\
(-0.05)\end{array}$ & $\begin{array}{l}-0.005 \\
(-1.31)\end{array}$ & -0.007 \\
\hline 3 & $\begin{array}{l}0.003 \\
(1.60)\end{array}$ & $\begin{array}{l}0.001 \\
(0.48)\end{array}$ & $\begin{array}{l}-0.004 \\
(-1.84)\end{array}$ & $\begin{array}{l}0.002 \\
(0.66)\end{array}$ & -0.001 \\
\hline 4 & $\begin{array}{c}0.004^{* *} \\
(2.69)\end{array}$ & $\begin{array}{l}0.004^{*} \\
(2.51)\end{array}$ & $\begin{array}{l}0.001 \\
(0.91)\end{array}$ & $\begin{array}{l}-0.003 \\
(-1.32)\end{array}$ & -0.007 \\
\hline 5 & $\begin{array}{l}0.002 \\
(1.48)\end{array}$ & $\begin{array}{l}0.002 \\
(1.42)\end{array}$ & $\begin{array}{l}-0.000 \\
(-0.22)\end{array}$ & $\begin{array}{l}0.000 \\
(0.06)\end{array}$ & -0.002 \\
\hline 6 & $\begin{array}{c}0.003^{* *} \\
(2.61)\end{array}$ & $\begin{array}{l}0.002 \\
(1.80)\end{array}$ & $\begin{array}{l}0.000 \\
(0.10)\end{array}$ & $\begin{array}{l}-0.002 \\
(-1.22)\end{array}$ & -0.005 \\
\hline 7 & $\begin{array}{l}0.001 \\
(1.25)\end{array}$ & $\begin{array}{l}0.002 \\
(1.91)\end{array}$ & $\begin{array}{l}0.002 \\
(1.93)\end{array}$ & $\begin{array}{l}-0.001 \\
(-0.70)\end{array}$ & -0.002 \\
\hline 8 & $\begin{array}{l}0.003^{*} \\
(2.27)\end{array}$ & $\begin{array}{l}0.001 \\
(0.56)\end{array}$ & $\begin{array}{l}0.001 \\
(0.75)\end{array}$ & $\begin{array}{l}-0.001 \\
(-0.57)\end{array}$ & -0.004 \\
\hline 9 & $\begin{array}{l}-0.000 \\
(-0.14)\end{array}$ & $\begin{array}{l}-0.002 \\
(-1.41)\end{array}$ & $\begin{array}{c}-0.003^{*} \\
(-2.13)\end{array}$ & $\begin{array}{l}-0.002 \\
(-1.28)\end{array}$ & -0.002 \\
\hline High & $\begin{array}{c}-0.005^{* * *} \\
(-3.83)\end{array}$ & $\begin{array}{c}-0.005^{* * *} \\
(-3.71)\end{array}$ & $\begin{array}{c}-0.008^{* * *} \\
(-5.42)\end{array}$ & $\begin{array}{c}-0.010^{* * *} \\
(-6.36)\end{array}$ & -0.005 \\
\hline High-Low & -0.011 & -0.005 & -0.002 & -0.008 & \\
\hline
\end{tabular}

Table 4: Abnormal Monthly Returns in Months [7-18] on Portfolios Sorted by Total Asset Growth and Debt Issuance. The table reports the intercepts from OLS regressions of monthly excess portfolio returns (value and equally weighted) for the 40 asset growth/debt issuance portfolios on the three Fama-French factors. Firms in sub-portfolios DI4 increase their debt the most and firms in DI4 increase their debt the least. The abnormal returns are shown for months [7-18] following December of the fiscal year which is used to construct the sorting criteria. The longest sample period is from 1968 to 2010. $t$-statistics are reported in brackets. Asterisks correspond to the following $p$-values: $* p<0.05, * * p<0.01, * * * p<0.001$. 


\begin{tabular}{|c|c|c|}
\hline & (i) & (ii) \\
\hline \multicolumn{3}{|c|}{ Panel A. Value Weighted } \\
\hline $\ln (1+\mathrm{TAG})_{y}$ & $\begin{array}{r}-0.006 \\
(0.99)\end{array}$ & \\
\hline $\ln \mathrm{TAG}_{y}$ & & $\begin{array}{r}-0.001 \\
(1.18)\end{array}$ \\
\hline $\ln \mathrm{DI}_{y}$ & $\begin{array}{l}-0.001 \\
(1.54)\end{array}$ & $\begin{array}{r}-0.001^{* *} \\
(3.24)\end{array}$ \\
\hline Constant & $\begin{array}{r}-0.002 \\
(0.87)\end{array}$ & $\begin{array}{l}-0.005 \\
(3.23)\end{array}$ \\
\hline$R^{2}$ & 0.018 & 0.030 \\
\hline \multicolumn{3}{|c|}{ Panel B. Equal Weighted } \\
\hline $\ln (1+\mathrm{TAG})_{y}$ & $\begin{array}{r}-0.007 \\
(1.40)\end{array}$ & \\
\hline $\ln \mathrm{TAG}_{y}$ & & $\begin{array}{r}-0.000 \\
(0.01)\end{array}$ \\
\hline $\ln \mathrm{DI}_{y}$ & $\begin{array}{r}-0.001^{* *} \\
(2.99)\end{array}$ & $\begin{array}{r}-0.002^{* * *} \\
(4.60)\end{array}$ \\
\hline Constant & $\begin{array}{c}-0.004 \\
(1.59)\end{array}$ & $\begin{array}{r}-0.006 \\
(3.97)\end{array}$ \\
\hline$R^{2}$ & 0.041 & 0.070 \\
\hline
\end{tabular}

Table 5: Regressions of Abnormal Returns for Months 7-18 on Asset Growth and Debt Issuance. The table reports the results of panel regressions of the abnormal returns over months 7-18 on the 40 asset growth/debt issuance portfolios (value and equally weighted) on the equal or value-weighted measures of asset growth and debt issuance of the securities in the portfolios. $T A G_{y}$ is total asset growth in year $y . D I_{y}$ is debt issuance in year $y$. The regressions that include $T A G$ include only observations for which $T A G>0$. All variables (except for log-variables and abnormal returns) are winsorized at the $1 \%$ level. The sample period is from 1968 to 2010 . $t$-statistics which are reported in brackets are based on Driscoll and Kraay (1998) standard errors. Asterisks correspond to the following $p$-values: $* p<0.05, * * p<0.01, * * * p<0.001$. 


\begin{tabular}{|c|c|c|c|c|}
\hline & (i) & (ii) & (iii) & (iv) \\
\hline \multicolumn{5}{|c|}{$\begin{array}{l}\text { Panel A. Value Weighted } \\
\end{array}$} \\
\hline$\Delta \mathrm{ROA}_{y+1}$ & $\begin{array}{r}0.045^{*} \\
(2.49)\end{array}$ & & & $\begin{array}{r}0.037 \\
(1.75)\end{array}$ \\
\hline$\Delta \mathrm{ROE}_{y+1}$ & & $\begin{array}{r}0.017^{* *} \\
(3.48)\end{array}$ & & $\begin{array}{r}0.006 \\
(0.88)\end{array}$ \\
\hline $\mathrm{FE}(y, y+1)$ & & & $\begin{array}{r}-0.013^{* *} \\
(-3.46)\end{array}$ & \\
\hline Constant & $\begin{array}{r}0.000 \\
(0.10)\end{array}$ & $\begin{array}{l}-0.000 \\
(-0.24)\end{array}$ & $\begin{array}{r}0.001 \\
(0.67)\end{array}$ & $\begin{array}{r}0.000 \\
(0.06)\end{array}$ \\
\hline$R^{2}$ & 0.017 & 0.017 & 0.015 & 0.018 \\
\hline \multicolumn{5}{|c|}{ Panel B. Equal Weighted } \\
\hline$\Delta \mathrm{ROA}_{y+1}$ & $\begin{array}{r}0.066^{* *} \\
(2.88)\end{array}$ & & & $\begin{array}{c}0.029 \\
(0.90)\end{array}$ \\
\hline$\Delta \mathrm{ROE}_{y+1}$ & & $\begin{array}{r}0.035^{* * *} \\
(6.20)\end{array}$ & & $\begin{array}{c}0.027^{*} \\
(2.46)\end{array}$ \\
\hline $\mathrm{FE}(y, y+1)$ & & & $\begin{array}{r}-0.010^{* *} \\
(-2.73)\end{array}$ & \\
\hline Constant & $\begin{array}{l}-0.000 \\
(-0.25)\end{array}$ & $\begin{array}{r}0.000 \\
(0.18)\end{array}$ & $\begin{array}{c}0.001 \\
(0.91)\end{array}$ & $\begin{array}{r}0.000 \\
(0.06)\end{array}$ \\
\hline$R^{2}$ & 0.028 & 0.048 & 0.012 & 0.045 \\
\hline
\end{tabular}

Table 6: Regression of Abnormal Returns for Months 7-18 on News. The table reports the results of panel regressions of the abnormal return over months 7-18 on the 40 asset growth/debt issuance portfolios (value and equally weighted) on selected variables which are the equal or valueweighted characteristics of the securities in the portfolios. $\Delta R O A_{y+1}\left(\Delta R O E_{y+1}\right)$ is the change in Return on Assets (Equity) from year $y$ to year $y+1 ; F E(y, y+1)$ is the average median analyst forecast error for earnings per share in year $y+1$ made in the last quarter of year $y$ scaled by the share price at the end of year $y$ : it is set to missing if the share price is below one dollar. The sample period is from 1968 to 2010. Regressions that include $F E(y, y+1)$ start in 1980. All variables (except for abnormal returns) are winsorized at the 1\% level. The sample period is from 1968 to 2010 . $t$-statistics which are reported in brackets are based on Driscoll and Kraay (1998) standard errors. Asterisks correspond to the following $p$-values: $* p<0.05, * * p<0.01, * * * p<0.001$. 


\begin{tabular}{|c|c|c|c|c|c|c|c|c|c|c|}
\hline \multirow[b]{3}{*}{ Debt Issuance: } & \multicolumn{10}{|c|}{ Panel A. Scaled Error in Forecast of year $y+1$ Earnings made in year $y-1$} \\
\hline & \multicolumn{5}{|c|}{ Value Weighted } & \multicolumn{5}{|c|}{ Equal Weighted } \\
\hline & $D I 1$ & $D I 2$ & $D I 3$ & DI4 & $D I 4-D I 1$ & $D I 1$ & $D I 2$ & $D I 3$ & DI4 & $D I 4-D I 1$ \\
\hline \multicolumn{11}{|l|}{ Asset Growth } \\
\hline Low & 0.115 & 0.168 & 0.295 & 0.136 & 0.021 & 0.207 & 0.254 & 0.326 & 0.255 & 0.048 \\
\hline 2 & 0.048 & 0.076 & 0.105 & 0.144 & 0.096 & 0.140 & 0.177 & 0.140 & 0.213 & 0.073 \\
\hline 3 & 0.020 & 0.081 & 0.168 & 0.222 & 0.202 & 0.077 & 0.147 & 0.180 & 0.188 & 0.111 \\
\hline 4 & 0.022 & 0.025 & 0.063 & 0.051 & 0.029 & 0.059 & 0.056 & 0.119 & 0.154 & 0.095 \\
\hline 5 & 0.015 & 0.017 & 0.012 & 0.058 & 0.043 & 0.036 & 0.025 & 0.035 & 0.129 & 0.093 \\
\hline 6 & 0.012 & 0.013 & 0.018 & 0.027 & 0.015 & 0.018 & 0.032 & 0.039 & 0.104 & 0.086 \\
\hline 7 & 0.006 & 0.010 & 0.011 & 0.027 & 0.021 & 0.024 & 0.030 & 0.025 & 0.088 & 0.064 \\
\hline 8 & 0.005 & 0.008 & 0.015 & 0.052 & 0.047 & 0.015 & 0.032 & 0.038 & 0.068 & 0.053 \\
\hline 9 & -0.001 & 0.013 & 0.014 & 0.023 & 0.024 & 0.028 & 0.034 & 0.027 & 0.066 & 0.038 \\
\hline High & 0.010 & 0.015 & 0.025 & 0.038 & 0.028 & 0.057 & 0.044 & 0.067 & 0.104 & 0.047 \\
\hline Average & 0.025 & 0.043 & 0.073 & 0.078 & 0.053 & 0.066 & 0.083 & 0.100 & 0.137 & 0.071 \\
\hline \multicolumn{11}{|c|}{ Panel B. Scaled Error in Forecast of year $y+1$ Earnings made in year $y$} \\
\hline & \multicolumn{5}{|c|}{ Value Weighted } & \multicolumn{5}{|c|}{$\begin{array}{r}\text { Equal Weighted } \\
\end{array}$} \\
\hline Debt Issuance: & $D I 1$ & $D I 2$ & $D I 3$ & DI4 & $D I 4-D I 1$ & $D I 1$ & $D I 2$ & $D I 3$ & $D I 4$ & $D I 4-D I 1$ \\
\hline \multicolumn{11}{|l|}{ Asset Growth } \\
\hline Low & 0.131 & 0.222 & 0.153 & 0.269 & 0.138 & 0.158 & 0.236 & 0.169 & 0.33 & 0.172 \\
\hline 2 & 0.046 & 0.085 & 0.074 & 0.239 & 0.193 & 0.11 & 0.171 & 0.165 & 0.236 & 0.126 \\
\hline 3 & 0.022 & 0.048 & 0.103 & 0.06 & 0.038 & 0.083 & 0.086 & 0.149 & 0.151 & 0.068 \\
\hline 4 & 0.013 & 0.03 & 0.022 & 0.041 & 0.028 & 0.042 & 0.051 & 0.084 & 0.121 & 0.079 \\
\hline 5 & 0.007 & 0.008 & 0.020 & 0.033 & 0.026 & 0.03 & 0.032 & 0.057 & 0.135 & 0.105 \\
\hline 6 & 0.006 & 0.009 & 0.008 & 0.028 & 0.022 & 0.008 & 0.024 & 0.037 & 0.116 & 0.108 \\
\hline 7 & 0.003 & 0.009 & 0.010 & 0.029 & 0.026 & 0.021 & 0.028 & 0.031 & 0.088 & 0.067 \\
\hline 8 & 0.008 & 0.007 & 0.008 & 0.035 & 0.027 & 0.024 & 0.037 & 0.038 & 0.071 & 0.047 \\
\hline 9 & 0.004 & 0.016 & 0.014 & 0.039 & 0.035 & 0.026 & 0.035 & 0.042 & 0.078 & 0.052 \\
\hline High & 0.018 & 0.020 & 0.027 & 0.036 & 0.018 & 0.053 & 0.065 & 0.090 & 0.104 & 0.051 \\
\hline Average & 0.026 & 0.045 & 0.044 & 0.081 & 0.053 & 0.0555 & 0.077 & 0.086 & 0.143 & 0.088 \\
\hline
\end{tabular}

Table 7: Scaled Error in Forecast of Year $y+1$ Earnings Made in Years $y$ and $y-1$. The table reports for the 40 asset growth/debt issuance portfolios the equal and value weighted averages of the median analyst forecast errors for year $y+1$ earnings scaled by the share price at the end of year $y$ or $y-1$. Firms in sub-portfolios DI4 increase their debt the most and firms in DI4 increase their debt the least. The sample period is from 1968 to 2010. 


\begin{tabular}{lrr}
\hline & (i) & (ii) \\
Dependent Variable & $\mathrm{FE}(y, y+1)$ & $\mathrm{FE}(y-1, y+1)$ \\
\hline $\mathrm{DI}_{y}$ & $0.111^{* * *}$ & $0.074^{* * *}$ \\
& $(5.08)$ & $(3.89)$ \\
$\mathrm{TAG}_{y}$ & $-0.064^{* * *}$ & $-0.055^{* * *}$ \\
& $(-5.13)$ & $(6.08)$ \\
Constant & $0.132^{* * *}$ & $0.122^{* * *}$ \\
& $(8.86)$ & $(12.81)$ \\
$R^{2}$ & 0.007 & 0.009 \\
Obs. & 21889 & 9992 \\
\hline
\end{tabular}

Table 8: Regressions of Earnings Forecast Errors on Asset Growth and Debt Issuance. The table reports results of panel regressions of individual firm scaled earnings forecast errors on asset growth, $T A G_{y}$, and debt issuance, $D I_{y}$. Firms are included in the regression only if their debt issuance is positive in year $y . F E(y, y+1)(F E(y-1, y+1))$ is the forecast error of earnings per share in year $y+1$ made at the end of year $y(y-1)$ scaled by the share price at the end of year $y(y-1) . t$-statistics which are reported in brackets are based on Driscoll and Kraay (1998) standard errors. Asterisks correspond to the following $p$-values: $* p<0.05, * * p<0.01, * * * p<0.001$. 


\begin{tabular}{|c|c|c|c|c|c|c|c|c|c|c|}
\hline Debt Issuance: & $D I 1$ & $D I 2$ & $D I 3$ & $D I 4$ & $D I 4-D I 1$ & $D I 1$ & $D I 2$ & $D I 3$ & $D I 4$ & $D I 4-D I 1$ \\
\hline Asset Growth & \multicolumn{5}{|c|}{ Value Weighted } & \multirow{2}{*}{\multicolumn{5}{|c|}{ Equal Weighted }} \\
\hline \multicolumn{6}{|c|}{ Panel A. Return on Assets year $y-1$} & & & & & \\
\hline Low & 0.013 & 0.008 & 0.004 & 0.030 & 0.017 & -0.041 & -0.045 & -0.052 & -0.045 & -0.004 \\
\hline 2 & 0.082 & 0.064 & 0.075 & 0.071 & -0.011 & 0.025 & 0.030 & 0.031 & 0.035 & 0.010 \\
\hline 3 & 0.091 & 0.105 & 0.082 & 0.098 & 0.007 & 0.072 & 0.070 & 0.059 & 0.056 & -0.016 \\
\hline 4 & 0.121 & 0.106 & 0.112 & 0.092 & -0.029 & 0.09 & 0.088 & 0.083 & 0.063 & -0.027 \\
\hline 5 & 0.136 & 0.116 & 0.107 & 0.121 & -0.015 & 0.105 & 0.098 & 0.089 & 0.083 & -0.022 \\
\hline 6 & 0.148 & 0.135 & 0.129 & 0.120 & -0.028 & 0.118 & 0.105 & 0.102 & 0.090 & -0.028 \\
\hline 7 & 0.172 & 0.143 & 0.126 & 0.130 & -0.042 & 0.133 & 0.113 & 0.104 & 0.094 & -0.039 \\
\hline 8 & 0.185 & 0.152 & 0.132 & 0.132 & -0.053 & 0.14 & 0.122 & 0.116 & 0.094 & -0.046 \\
\hline 9 & 0.185 & 0.173 & 0.147 & 0.137 & -0.048 & 0.147 & 0.134 & 0.124 & 0.104 & -0.043 \\
\hline High & 0.169 & 0.160 & 0.151 & 0.145 & -0.024 & 0.128 & 0.126 & 0.127 & 0.103 & -0.025 \\
\hline \multicolumn{11}{|c|}{ Panel B. Return on Equity year $y-1$} \\
\hline Low & -0.087 & -0.064 & -0.118 & -0.158 & -0.071 & -0.163 & -0.167 & -0.193 & -0.261 & -0.098 \\
\hline 2 & 0.068 & 0.009 & 0.057 & -0.004 & -0.072 & -0.042 & -0.040 & -0.037 & -0.084 & -0.042 \\
\hline 3 & 0.098 & 0.125 & 0.057 & 0.116 & 0.018 & 0.04 & 0.041 & 0.030 & 0.006 & -0.034 \\
\hline 4 & 0.155 & 0.137 & 0.147 & 0.110 & -0.045 & 0.091 & 0.098 & 0.074 & 0.027 & -0.064 \\
\hline 5 & 0.150 & 0.158 & 0.152 & 0.151 & 0.001 & 0.111 & 0.115 & 0.102 & 0.065 & -0.046 \\
\hline 6 & 0.175 & 0.190 & 0.182 & 0.153 & -0.022 & 0.129 & 0.128 & 0.124 & 0.089 & -0.040 \\
\hline 7 & 0.185 & 0.198 & 0.188 & 0.164 & -0.021 & 0.141 & 0.134 & 0.129 & 0.093 & -0.048 \\
\hline 8 & 0.209 & 0.203 & 0.185 & 0.164 & -0.045 & 0.149 & 0.139 & 0.146 & 0.088 & -0.061 \\
\hline 9 & 0.215 & 0.213 & 0.190 & 0.168 & -0.047 & 0.152 & 0.151 & 0.148 & 0.112 & -0.040 \\
\hline High & 0.204 & 0.199 & 0.184 & 0.170 & -0.034 & 0.112 & 0.135 & 0.130 & 0.098 & -0.014 \\
\hline \multicolumn{11}{|c|}{ Panel C. Market to Book Ratio year $y-1$} \\
\hline Low & 2.187 & 2.369 & 2.278 & 2.691 & 0.504 & 2.075 & 1.916 & 1.767 & 2.491 & 0.416 \\
\hline 2 & 1.887 & 1.832 & 2.421 & 2.598 & 0.711 & 1.662 & 1.585 & 1.754 & 2.082 & 0.420 \\
\hline 3 & 2.108 & 2.092 & 1.785 & 2.730 & 0.622 & 1.717 & 1.603 & 1.463 & 1.878 & 0.161 \\
\hline 4 & 2.499 & 2.135 & 2.432 & 2.313 & -0.186 & 1.685 & 1.646 & 1.607 & 1.682 & -0.003 \\
\hline 5 & 2.369 & 2.470 & 2.349 & 2.848 & 0.479 & 1.796 & 1.761 & 1.658 & 1.935 & 0.139 \\
\hline 6 & 2.837 & 2.404 & 2.746 & 2.427 & -0.41 & 2.089 & 1.835 & 1.822 & 1.862 & -0.227 \\
\hline 7 & 3.277 & 2.961 & 2.837 & 2.916 & -0.361 & 2.229 & 1.998 & 1.919 & 1.925 & -0.304 \\
\hline 8 & 3.840 & 3.188 & 2.903 & 2.565 & -1.275 & 2.536 & 2.185 & 2.092 & 1.963 & -0.573 \\
\hline 9 & 4.124 & 3.812 & 3.273 & 3.035 & -1.089 & 3.076 & 2.481 & 2.316 & 2.305 & -0.771 \\
\hline High & 4.283 & 3.749 & 3.600 & 4.034 & -0.249 & 3.449 & 2.708 & 2.692 & 3.038 & -0.411 \\
\hline \multicolumn{11}{|c|}{ Panel D. Leverage Ratio year $y-1$} \\
\hline & $D I 1$ & DI2 & $D I 3$ & DI4 & $D I 4-D I 1$ & $D I 1$ & $D I 2$ & $D I 3$ & DI4 & $D I 4-D I 1$ \\
\hline Low & 0.235 & 0.247 & 0.246 & 0.260 & 0.025 & 0.195 & 0.212 & 0.223 & 0.232 & 0.037 \\
\hline 2 & 0.233 & 0.248 & 0.273 & 0.257 & 0.024 & 0.230 & 0.264 & 0.272 & 0.255 & 0.025 \\
\hline 3 & 0.240 & 0.261 & 0.281 & 0.257 & 0.017 & 0.257 & 0.289 & 0.299 & 0.285 & 0.028 \\
\hline 4 & 0.227 & 0.266 & 0.280 & 0.290 & 0.063 & 0.259 & 0.296 & 0.308 & 0.294 & 0.035 \\
\hline 5 & 0.231 & 0.305 & 0.327 & 0.288 & 0.057 & 0.259 & 0.319 & 0.328 & 0.290 & 0.031 \\
\hline 6 & 0.221 & 0.270 & 0.307 & 0.288 & 0.067 & 0.246 & 0.302 & 0.321 & 0.307 & 0.061 \\
\hline 7 & 0.190 & 0.274 & 0.314 & 0.291 & 0.101 & 0.218 & 0.287 & 0.316 & 0.318 & 0.100 \\
\hline 8 & 0.173 & 0.252 & 0.295 & 0.293 & 0.120 & 0.198 & 0.263 & 0.291 & 0.300 & 0.102 \\
\hline 9 & 0.170 & 0.236 & 0.290 & 0.276 & 0.106 & 0.191 & 0.253 & 0.281 & 0.295 & 0.104 \\
\hline High & 0.184 & 0.254 & 0.276 & 0.275 & 0.091 & 0.179 & 0.258 & 0.275 & 0.278 & 0.099 \\
\hline \multicolumn{11}{|c|}{ Panel E. Abnormal Returns months -23 to -11} \\
\hline Low & -0.016 & -0.021 & -0.024 & -0.020 & -0.004 & -0.011 & -0.017 & -0.018 & -0.015 & -0.004 \\
\hline 2 & -0.015 & -0.015 & -0.012 & -0.010 & 0.005 & -0.015 & -0.014 & -0.013 & -0.008 & 0.007 \\
\hline 3 & -0.009 & -0.008 & -0.014 & -0.013 & -0.004 & -0.005 & -0.009 & -0.007 & -0.008 & -0.003 \\
\hline 4 & -0.003 & -0.001 & -0.006 & -0.007 & -0.004 & -0.004 & -0.005 & -0.006 & -0.006 & -0.002 \\
\hline 5 & -0.003 & -0.003 & -0.001 & -0.005 & -0.002 & -0.001 & -0.002 & -0.004 & -0.002 & -0.001 \\
\hline 6 & 0.001 & 0.002 & -0.002 & -0.003 & -0.004 & 0.002 & 0 & -0.001 & -0.001 & -0.003 \\
\hline 7 & 0.002 & 0.002 & -0.001 & 0.002 & 0.000 & 0.004 & 0.002 & 0.000 & 0.001 & $-0.003^{*}$ \\
\hline 8 & 0.009 & 0.003 & 0.002 & -0.003 & $-0.012 * * *$ & 0.008 & 0.008 & 0.005 & 0.001 & $-0.007 * * *$ \\
\hline 9 & 0.011 & 0.005 & 0.007 & 0.002 & $-0.009 * * *$ & 0.015 & 0.011 & 0.009 & 0.004 & $-0.011^{* * *}$ \\
\hline High & 0.016 & 0.008 & 0.007 & 0.009 & $-0.007 * * *$ & 0.030 & 0.020 & 0.015 & 0.022 & $-0.008^{* * *}$ \\
\hline
\end{tabular}

Table 9: Measures of Pressure on the Managers. The table reports equally weighted and value weighted characteristics of the firms in the 40 asset growth/debt issuance portfolios that affect the pressure on management to 'make the numbers'. Firms in sub-portfolios DI4 increase their debt the most and firms in DI4 increase their debt the least. The sample period is from 1968 to 2010. Asterisks correspond to the following $p$-values: $* p<0.05, * * p<0.01, * * * p<0.001$. 


\begin{tabular}{|c|c|c|c|c|c|c|c|c|c|c|}
\hline Debt Issuance: & $D I 1$ & $D I 2$ & DI3 & $D I 4$ & $D I 4-D I 1$ & $D I 1$ & $D I 2$ & DI3 & DI4 & $D I 4-D I 1$ \\
\hline Asset Growth & \multicolumn{5}{|c|}{ Panel A. New CEO in $y-1$ or $y$} & \multicolumn{5}{|c|}{ Panel B. New CEO in $y+1$ or $y+2$ or $y+3$} \\
\hline Low & 0.250 & 0.133 & 0.156 & 0.136 & -0.114 & 0.114 & 0.133 & 0.250 & 0.273 & 0.159 \\
\hline 2 & 0.133 & 0.254 & 0.244 & 0.200 & 0.067 & 0.120 & 0.169 & 0.222 & 0.150 & 0.030 \\
\hline 3 & 0.109 & 0.088 & 0.122 & 0.118 & 0.009 & 0.109 & 0.184 & 0.122 & 0.132 & 0.023 \\
\hline 4 & 0.071 & 0.122 & 0.057 & 0.123 & 0.052 & 0.093 & 0.169 & 0.101 & 0.090 & -0.003 \\
\hline 5 & 0.031 & 0.053 & 0.060 & 0.116 & 0.085 & 0.059 & 0.120 & 0.137 & 0.191 & 0.132 \\
\hline 6 & 0.043 & 0.052 & 0.074 & 0.093 & 0.050 & 0.096 & 0.112 & 0.111 & 0.134 & 0.038 \\
\hline 7 & 0.056 & 0.067 & 0.065 & 0.067 & 0.011 & 0.106 & 0.113 & 0.089 & 0.151 & 0.045 \\
\hline 8 & 0.036 & 0.051 & 0.045 & 0.078 & 0.042 & 0.088 & 0.086 & 0.107 & 0.092 & 0.004 \\
\hline 9 & 0.045 & 0.047 & 0.036 & 0.089 & 0.044 & 0.128 & 0.067 & 0.072 & 0.099 & -0.029 \\
\hline High & 0.028 & 0.050 & 0.039 & 0.035 & 0.007 & 0.099 & 0.112 & 0.142 & 0.106 & 0.007 \\
\hline
\end{tabular}

Table 10: Proportions of New CEO's. The table reports the proportions of firms in each of the 40 asset growth/debt issuance portfolios that appointed new CEOs around year $y$. Firms in sub-portfolios DI4 increase their debt the most and firms in DI4 increase their debt the least. The sample period is from 1992 to 2010.

\begin{tabular}{|c|c|c|c|c|c|c|c|}
\hline \multicolumn{8}{|c|}{ Standard Deviation of Change in Return on Assets from year y to year $y+1$} \\
\hline $\begin{array}{l}\text { Debt Issuance: } \\
\text { Asset Growth }\end{array}$ & $D I 1$ & $D I 2$ & $D I 3$ & $D I 4$ & $D I 4-D I 1$ & $\begin{array}{r}D I 4 \text { minus } \\
\text { Avg. }(D I 2, D I 3)\end{array}$ & $\begin{array}{r}D I 1 \text { minus } \\
\text { Avg. }(D I 2, D I 3)\end{array}$ \\
\hline Low & 0.194 & 0.179 & 0.201 & 0.235 & 0.041 & 0.045 & 0.004 \\
\hline 2 & 0.108 & 0.111 & 0.119 & 0.144 & 0.036 & 0.029 & -0.007 \\
\hline 3 & 0.064 & 0.079 & 0.085 & 0.112 & 0.048 & 0.030 & -0.018 \\
\hline 4 & 0.064 & 0.056 & 0.064 & 0.094 & 0.030 & 0.034 & 0.004 \\
\hline 5 & 0.060 & 0.053 & 0.053 & 0.083 & 0.023 & 0.030 & 0.007 \\
\hline 6 & 0.061 & 0.048 & 0.057 & 0.073 & 0.012 & 0.021 & 0.008 \\
\hline 7 & 0.065 & 0.060 & 0.056 & 0.080 & 0.015 & 0.022 & 0.007 \\
\hline 8 & 0.084 & 0.070 & 0.066 & 0.092 & 0.008 & 0.024 & 0.016 \\
\hline 9 & 0.101 & 0.081 & 0.082 & 0.096 & -0.005 & 0.015 & 0.020 \\
\hline High & 0.171 & 0.126 & 0.125 & 0.187 & 0.016 & 0.062 & 0.046 \\
\hline Average & 0.097 & 0.086 & 0.091 & 0.120 & 0.022 & 0.031 & 0.009 \\
\hline
\end{tabular}

Table 11: Risk Characteristics. The table reports the time series average of the cross-sectional standard deviation of the change in the Return on Assets from year $y$ to year $y+1$ for the the 40 asset growth/debt issuance portfolios. Firms in sub-portfolios DI4 increase their debt the most and firms in DI4 increase their debt the least. The sample period is from 1968 to 2010. 


\begin{tabular}{|c|c|c|c|c|c|c|c|c|}
\hline & (i) & (ii) & (iii) & (iv) & (v) & (vi) & (vii) & (viii) \\
\hline \multirow{2}{*}{$(\mathrm{D} / \mathrm{A})_{y-1}$} & $-0.209^{* * *}$ & $-0.220^{* * *}$ & $-0.198^{* * *}$ & $-0.199^{* * *}$ & $-0.229^{* * *}$ & $-0.241^{* * *}$ & $-0.217^{* * *}$ & $-0.237 * * *$ \\
\hline & $(-13.49)$ & $(-11.17)$ & $(-15.16)$ & $(-11.57)$ & $(-15.43)$ & $(-12.50)$ & $(-18.91)$ & $(-10.32)$ \\
\hline \multirow{2}{*}{$(\mathrm{D} / \mathrm{A})_{y-1} \times \mathrm{TAG}_{y}$} & $0.407^{* * *}$ & $0.471^{* * *}$ & $0.337^{* * * *}$ & $0.395^{* * *}$ & $0.360 * * *$ & $0.441 * * *$ & $0.258^{* * *}$ & $0.142^{*}$ \\
\hline & (19.40) & $(21.24)$ & (10.65) & (14.08) & $(14.50)$ & (13.53) & $(7.51)$ & $(2.68)$ \\
\hline \multirow[t]{2}{*}{$\mathrm{TAG}_{y}$} & $0.265^{* * *}$ & & $0.326^{* * *}$ & & $0.293^{* * *}$ & & $0.360 * * *$ & $0.369^{* * *}$ \\
\hline & $(24.42)$ & & (26.96) & & (21.23) & & $(25.48)$ & $(26.54)$ \\
\hline \multirow[t]{2}{*}{$\mathrm{ROA}_{y}$} & $-0.196^{* * *}$ & 0.025 & $-0.264^{* * *}$ & -0.035 & $-0.221^{* * *}$ & 0.020 & $-0.330 * * *$ & $-0.211^{* * *}$ \\
\hline & $(-8.49)$ & $(1.22)$ & $(-14.14)$ & $(-2.04)$ & $(-5.63)$ & $(0.59)$ & $(-10.80)$ & $(-4.18)$ \\
\hline \multirow[t]{2}{*}{$\operatorname{Ret}_{y}$} & $-0.019 * * *$ & $-0.015^{* * *}$ & $-0.015^{* * *}$ & $-0.009 * * *$ & $-0.024 * * *$ & $-0.020 * * *$ & $-0.017^{* * *}$ & $-0.020^{* *}$ \\
\hline & $(-11.01)$ & $(-9.06)$ & $(-5.88)$ & $(-5.29)$ & $(-11.04)$ & $(-6.87)$ & $(-4.51)$ & $(-3.10)$ \\
\hline \multirow[t]{2}{*}{$\operatorname{Ret}_{y-1}$} & $-0.012^{* * *}$ & $-0.011 * * *$ & $-0.007^{* * *}$ & $-0.006^{* * *}$ & $-0.018^{* * *}$ & $-0.017^{* * *}$ & $-0.011 * * *$ & $-0.015 * * *$ \\
\hline & $(-5.77)$ & $(-5.74)$ & $(-5.27)$ & $(-4.88)$ & $(-5.57)$ & $(-4.12)$ & $(-6.31)$ & $(-4.52)$ \\
\hline \multirow[t]{2}{*}{$\mathrm{SDROA}_{y+1}$} & $-0.172^{* *}$ & $-0.157^{*}$ & $-0.197 * * *$ & $-0.130^{*}$ & $-0.170^{*}$ & $-0.172^{*}$ & $-0.153^{*}$ & $-0.305 * * *$ \\
\hline & $(-2.93)$ & $(-2.50)$ & $(-3.60)$ & $(-2.36)$ & $(-2.43)$ & $(-2.34)$ & $(-2.57)$ & $(-4.25)$ \\
\hline \multirow[t]{2}{*}{$\Delta \mathrm{ROA}_{y}$} & 0.012 & 0.020 & $-0.077 * * *$ & $-0.041^{*}$ & 0.029 & $0.050^{*}$ & $-0.050^{*}$ & $-0.126 * * *$ \\
\hline & $(0.87)$ & $(1.21)$ & $(-3.92)$ & $(-2.24)$ & (1.66) & $(2.48)$ & $(-2.53)$ & $(-5.26)$ \\
\hline \multirow[t]{2}{*}{$(\mathrm{M} / \mathrm{B})_{y-1}$} & $-0.002^{* * *}$ & $-0.003^{* * *}$ & -0.000 & -0.001 & -0.000 & $-0.001^{*}$ & 0.001 & 0.001 \\
\hline & $(-4.79)$ & $(-6.27)$ & $(-0.44)$ & $(-1.70)$ & $(-0.26)$ & $(-2.64)$ & $(2.06)$ & (1.44) \\
\hline \multirow[t]{2}{*}{$\Delta \mathrm{ROA}_{y+1}$} & $-0.086^{* * *}$ & $-0.065^{* * *}$ & $-0.065^{* * *}$ & $-0.031 * *$ & $-0.069 * *$ & $-0.058^{*}$ & $-0.047 * *$ & -0.041 \\
\hline & $(-5.57)$ & $(-4.50)$ & $(-7.19)$ & $(-2.93)$ & $(-3.09)$ & $(-2.22)$ & $(-3.43)$ & $(-1.94)$ \\
\hline \multirow[t]{2}{*}{$(\mathrm{DI}+\mathrm{SI})_{y}$} & & $0.302^{* * *}$ & & $0.392^{* * *}$ & & $0.332^{* * *}$ & & \\
\hline & & $(16.20)$ & & $(17.85)$ & & $(15.42)$ & & \\
\hline \multirow[t]{2}{*}{$((\mathrm{E} / \mathrm{P}) / \mathrm{Baa})_{y-1}$} & & & $0.003^{*}$ & 0.001 & & & $0.005^{*}$ & 0.003 \\
\hline & & & $(2.09)$ & $(0.88)$ & & & $(2.21)$ & $(1.20)$ \\
\hline \multirow[t]{2}{*}{$\mathrm{FE}(y-1, y)$} & & & & & $0.030^{* * *}$ & $0.020^{* * *}$ & $0.025^{* *}$ & 0.030 \\
\hline & & & & & $(4.08)$ & (4.83) & $(3.12)$ & (1.61) \\
\hline CEOstart $_{y-1, y}$ & & & & & & & & $\begin{array}{r}0.008 \\
(1.77)\end{array}$ \\
\hline $\mathrm{SENSI}_{y}$ & & & & & & & & $\begin{array}{r}-0.020^{*} \\
(-2.45)\end{array}$ \\
\hline \multirow[t]{2}{*}{ Constant } & $0.158^{* * *}$ & $0.139 * * *$ & $0.136^{* * *}$ & $0.113^{* * *}$ & $0.167^{* * *}$ & $0.151^{* * *}$ & $0.145^{* * *}$ & $0.159^{* * *}$ \\
\hline & (13.73) & (10.30) & (15.19) & $(9.86)$ & $(12.56)$ & $(9.38)$ & (14.77) & (13.40) \\
\hline$R^{2}$ & 0.587 & 0.621 & 0.636 & 0.690 & 0.595 & 0.627 & 0.647 & 0.670 \\
\hline Obs. & 33806 & 29957 & 27845 & 24552 & 18858 & 15821 & 15978 & 5120 \\
\hline
\end{tabular}

Table 12: Regressions of Debt Issuance. The table reports the results of panel regressions of debt issuance in year $y$ on several explanatory variables. Firms are included in the regression only if their debt issuance is positive in year $y .(D / A)_{y-1}$ is the lagged debt ratio. Ret $_{y}$ and $\operatorname{Ret}_{y-1}$ are the stock returns in the current and previous year. Operating risk, $S D R O A_{y+1}$, is measured by the standard deviation of the change in Return on Assets between years $y$ and $y+1$ for all firms within the same asset growth/debt issuance portfolio. For regressions that involve the relative earnings yield, $((E / P) / B a a)_{y-1}$, only firms with positive earnings in year $y-1$ are included. $S E N S I_{y}$ is the product of the share price and the sum of the number of shares and one half the number of unexercised options held by the CEO (normalized by the CEO's base salary). CEOstart ${ }_{y-1, y}$ is a dummy variable equal to one if a new CEO was appointed in year $y-1$ or $y$. $F E(y-1, y)$ is the scaled error in the forecast of earnings per share in year $y$ made at the end of $y-1$. The definitions of the other variables can be found in Section 5. All variables are winsorized at the $0.1 \%$ level. The longest sample period is 1968 to 2010. $t$-statistics which are reported in brackets are based on Driscoll and Kraay (1998) standard errors. Asterisks correspond to the following $p$-values: $* p<0.05, * * p<0.01, * * * p<0.001$. 


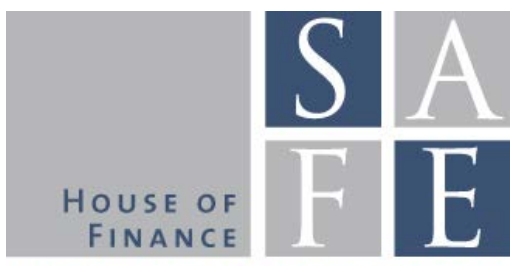

WORKING PAPER SERIES

\section{Recent Issues}

No.118 Michael Donadelli, Antonio

Paradiso, Max Riedel

No. 117 Marcel Bluhm

No. 116 Charles Gottlieb

No. 115 Andreas Fagereng, Charles Gottlieb, Luigi Guiso

No. 114 Nicole Branger, Christian Schlag, Lue $\mathrm{Wu}$

No. 113 Bettina Brüggemann, Jinhyuk Yoo

No. 112 Shafik Hebous, Alfons J.

Weichenrieder

No.111 Alfons J. Weichenrieder, Fangying $\mathrm{Xu}$

No. 110 Dirk Krueger, Alexander Ludwig

No. 109 Tobias Tröger

No. 108 Sascha Baghestanian, Paul Gortner, Baptiste Massenot

No. 107 Daniel Powell, Marc Steffen Rapp

No. 106 Baptiste Massenot, Stéphane Straub

No. 105
Vilen Lipatov, Alfons J. Weichenrieder
A Novel Ex-Ante Leading Indicator for the EU Industrial Production

Interbank Funding as Insurance Mechanism for (Persistent) Liquidity Shocks

On the Distributive Effects of Inflation

Asset Market Participation and Portfolio Choice over the Life-Cycle

'Nobody is Perfect': Asset Pricing and Long-Run Survival When Heterogeneous Investors Exhibit Different Kinds of Filtering Errors

Aggregate and Distributional Effects of Increasing Taxes on Top Income Earners

On Deficits and Symmetries in a Fiscal Capacity

Are Tax Havens Good? Implications of the Crackdown on Secrecy

On the Optimal Provision of Social Insurance

Regulatory Influence on Market Conditions in the Banking Union

Compensation Schemes, Liquidity Provision, and Asset Prices: An Experimental Analysis

Non-Mandatory Say on Pay Votes and AGM Participation: Evidence from Germany Informal Sector and Economic Development: The Credit Supply Channel

A Decentralization Theorem of Taxation 